\title{
Rendas de ferro: uma doação pela memória civilizatória brasileira ${ }^{1}$
}

Iron lace: a donation for the Brazilian civilizing memory

https://doi.org/10.1590/1982-02672021v29e12

\author{
IRINA ARAGÃO DOS SANTOS² \\ https://orcid.org/0000-0002-1635-2495 \\ Pontifícia Universidade Católica do Rio de Janeiro / Rio de Janeiro, RJ, Brasil
}

RESUMO: Este artigo é um estudo histórico e historiográfico a partir de objeto museológico, um colar que é exemplar do Ferro de Berlim, tipo europeu em voga na primeira metade do século XIX, e de sua ficha catalográfica. O colar, cuja ficha catalográfica atribui a construção à Real Fábrica de Ferro São João do lpanema, de São Paulo, foi, supostamente, presente dedicado à Dona Teresa Cristina. ○ objeto e sua ficha catalográfica são indícios para a reflexão e o levantamento de hipóteses sobre a doação feita pela memória civilizatória brasileira. Ao longo da pesquisa por referências para a proposição de uma biografia do objeto, surgiram incógnitas e outras possibilidades foram identificadas para a peça, que reiteram a potência da cultura material como documento histórico.

PALAVRAS-CHAVE: Colar. Ferro de Berlim. São João do Ipanema. Cultura material. Objeto museológico.

ABSTRACT: This is a historical and historiographical study based on a museum object and its catalogue card (object description and information about it). The necklace - a Berlin Iron exemplar, a fashionable European product in the first half of the 19th century - and its museum

\begin{abstract}
1. Este texto foi organizado a partir da pesquisa de pós-doutorado, realizada sob supervisão da Profa. Dra. Heloisa Meireles Gesteira, junto ao Núcleo de Estudos Históricos de Artefatos da Ciência e Tecnologia (NEHACT), do Museu da Astronomia e Ciências Afins (MAST), no Rio de Janeiro. A pesquisa foi encerrada ao final de 2019. Agradeço pelo diálogo e gentil acolhimento à Profa. Dra. Heloisa Meireles Gesteira e ao NEHACT/MAST; ao Prof. Dr. Paulo Knauss e à equipe do Museu Histórico Nacional; a Richard Edgcumbe, curador da Coleção de Objetos de Metal, do Victoria and Albert Museum (Londres, Inglaterra); Judy Rudoe, curadora e pesquisadora do British Museum (Londres, Inglaterra); Alexandra Bocc, curadora do Musée Le Secq des Tournelles (Rouen, França); Helen Lindroth, curadora do Nordiska Museet (Estocolmo, Suécia); aos Achim Feller e Profs. Drs. Cesar Roberto de Farias Azevedo e Fernando José Gomes Landgraf da Escola Politécnica da Universidade de São Paulo (USP); a Adilson José
\end{abstract}


de Almeida, supervisor de acervo do Museu Paulista (USP) e à Profa.Maria de Fátima Duarte Henrique dos Santos.

2. Tem pós-doutorado em História da Ciência e Tecnologia, no Núcleo de Estudos Históricos de Artefatos da Ciência e Tecnologia, Museu de Astronomia e Ciências Afins (MAST). Doutora em História Comparada, pelo Instituto de História da Universidade Federal do Rio de Janeiro (UFRJ). Ministra as disciplinas de História e Projeto de Design, e Design de Adornos Pessoais no curso de graduação em Design na Pontifícia Universidade Católica do Rio de Janeiro (PUC-Rio). E-mail: <irinaa@uol.com.br>. catalogue card, which attributes its construction to the Royal Iron Factory São João do Ipanema, from São Paulo, and supposedly a gift dedicated to the Empress Teresa Cristina, are indications for hypotheses and reflection on the donation made as a confirmation of the Brazilian civilizing memory. Throughout the search for references for proposing a biography of the object, uncertainties emerged and other possibilities were identified for the piece, which reiterate the huge potential of the material culture as a historical document.

KEYWORDS: Necklace. Berlin Iron. São João do lpanema. Material culture. Museum documentation. 


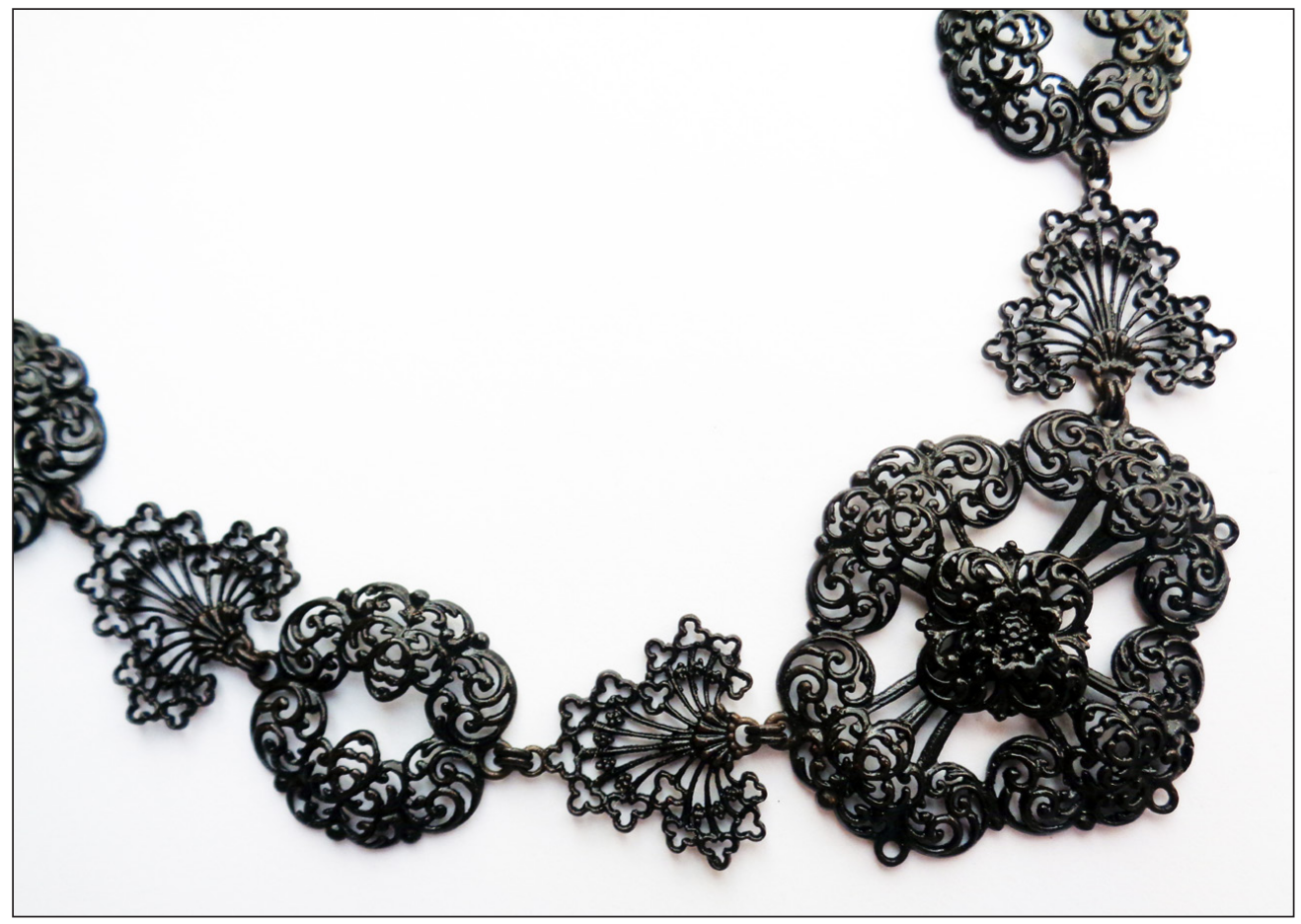

Figura 1 - Colar de ferro. Fonte: Acervo do Museu Histórico Nacional, Rio de Janeiro.

A peça 13223, pertencente ao acervo do Museu Histórico Nacional, foi documentada por meio da seguinte ficha catalográfica:

"13223 - Localização atual: Exposição sala 2 - Objeto: colar - Classe: 12.5 - Objeto de Adorno - Autor/Fábrica: Fábrica de Ferro lpanema - Local/País: Brasil - São Paulo - Data: 1846 - Fonte: diretoria Geral dos Correios, Rio de Janeiro, RJ - Forma: Doação - Processo: 15/1927 - Conservação: Bom - Materiais: Ferro - Técnicas: em pesquisa - Obs.: Colar feito de ferro finamente trabalhado em rosáceas e palmas intercaladas, tendo ao centro um medalhão em tamanho maior. Fecho no mesmo material. Elo de fixação solto na peça que fecha. Pertenceu à Imperatriz Dona Teresa Cristina e foi feito com o primeiro ferro extraído das minas que serviram à Real Fábrica de Ferro de Ipanema, ou Fundição Ypanema (siderúrgica que existiu na região de Sorocaba, no atual Município de lperó, interior do estado de São Paulo). [...] Em 1846 os imperadores visitaram a Fábrica de Ferro Ipanema".

Ao primeiro olhar, identificamos um colar composto por um elemento central e dois componentes distintos que se intercalam, articulados por pequenos elos duplos (Figuras 1 e 2), e um fecho tipo palheta ${ }^{3}$ decorado com uma flor (Figura 3). $\bigcirc$ conjunto nos sugere uma renda preta. Chama atenção a delicada e vaporosa composição e o material incomum na construção de adornos pessoais: ${ }^{4}$ o ferro. $\bigcirc$
3. O fecho tipo palheta ou gaveta é formado por uma caixa que recebe uma lingueta plana, que possui parte não fixa, em rampa, que desempenha a função de mola, unindo as duas partes.

4. "Os termos adorno pessoal e objeto de adorno pessoal foram adotados para definir os objetos usados sobre o corpo e/ou intervenções feitas no corpo tais como pinturas, tatuagens, escarificações, body modifications, como extensão de pensamentos, meios de expressar e comunicar ideias ou um diálogo do sujeito com os próprios valores $\mathrm{e}$ os modelos sociais. São classificadores, demarcadores, mediadores e meios sinaléticos de representar situações, condições, relações, ritos, padrões e códigos de conduta em sociedade, discursos e representações de um indivíduo e/ou grupo em um contexto histórico" (Santos, 2014, p. 17). Cf. Santos (2014, p. 16-37). 
5. "A expansão territorial da colônia em direção ao oeste foi resultado de movimentos como as missões jesuíticas e expedições realizadas em busca de índios e metais preciosos no interior, chamadas bandeiras, entradas e monções. Gradativamente, essas ações diversificaram as atividades econômicas no período colonial e, ao dar origem a novas vilas e povoados, tornaram-se pontos de articulação entre a produção no interior e a exportação no litoral. Alargaram as fronteiras, contribuindo para a atual configuração territorial do Brasil" (texto em exposição no Museu Histórico Nacional, referente à temática "Rumo ao Oeste").

6. "A descoberta de ouro e diamante, nos séculos XVII e XVIII, teve grande impacto no Brasil e em Portugal. Provocou o primeiro grande fluxo migratório da Metrópole para a Colônia, bem como o deslocamento de pessoas de diferentes partes do Brasil para as regiões das minas, dando início a novas vilas e povoados. O comércio de escravos intensificouse em decorrência da maior demanda de mão de obra e do alto índice de mortalidade na produção mineradora. Atualmente o Brasil está entre os países com maior potencial de mineração do mundo" (texto em exposição no Museu Histórico Nacional, referente à temática "Riqueza da Terra").

7. O colar é composto por peça central ovalada e levemente abaulada em motivos florais estilizados, formada por centro em flor dobrada e quatro ornamentos que delimitam o contorno e a base da peça, que tem volume por sobreposição. O miolo e a base são fixados por rebite. As volutas e as linhas orgânicas - sinuosas e curvas -, com largura aproximada de $2 \mathrm{~mm}$, configuram espaços cheios e va- colar faz parte do acervo do Museu Histórico Nacional, no Rio de Janeiro, e é exposto na sala 2, que aborda as temáticas "Rumo ao Oeste"5 e "Riqueza da Terra", 6 referentes à economia, às riquezas e práticas fabris no Brasil colonial e imperial.

O cenário da sala do Museu diz pouco sobre o colar, e sua identificação menciona apenas que este foi presente entregue à Imperatriz Dona Teresa Cristina pela Real Fábrica de Ferro São João do Ipanema, de São Paulo. Mas por que um colar de ferro? Fábricas de ferro no Brasil faziam itens da moda como colares? $\mathrm{E}$ por que este foi feito e presenteado à Dona Teresa Cristina? Que trajetória o colar percorreu de sua fabricação à coleção do Museu? Quais códigos ele representou?

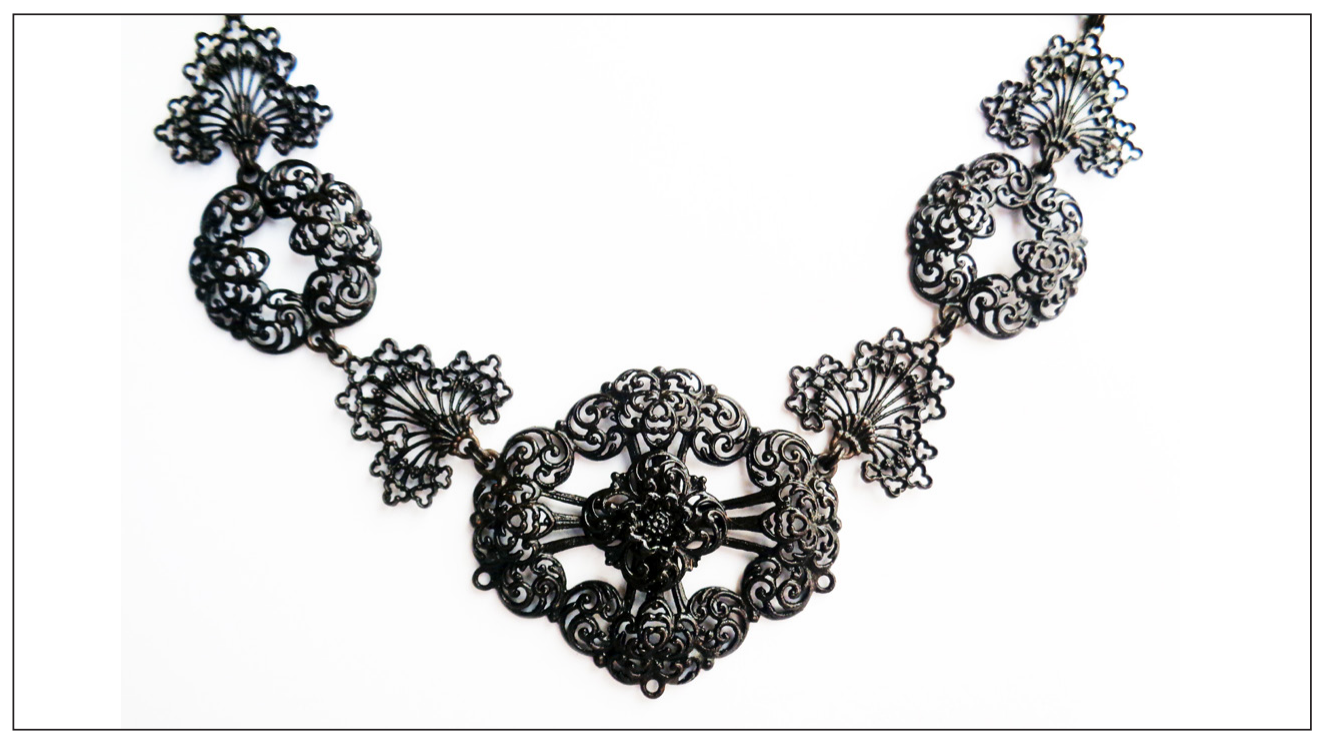

Figura 2 - Colar composto por peça central e dois elementos repetidores.? Fonte: Acervo do Museu Histórico Nacional.

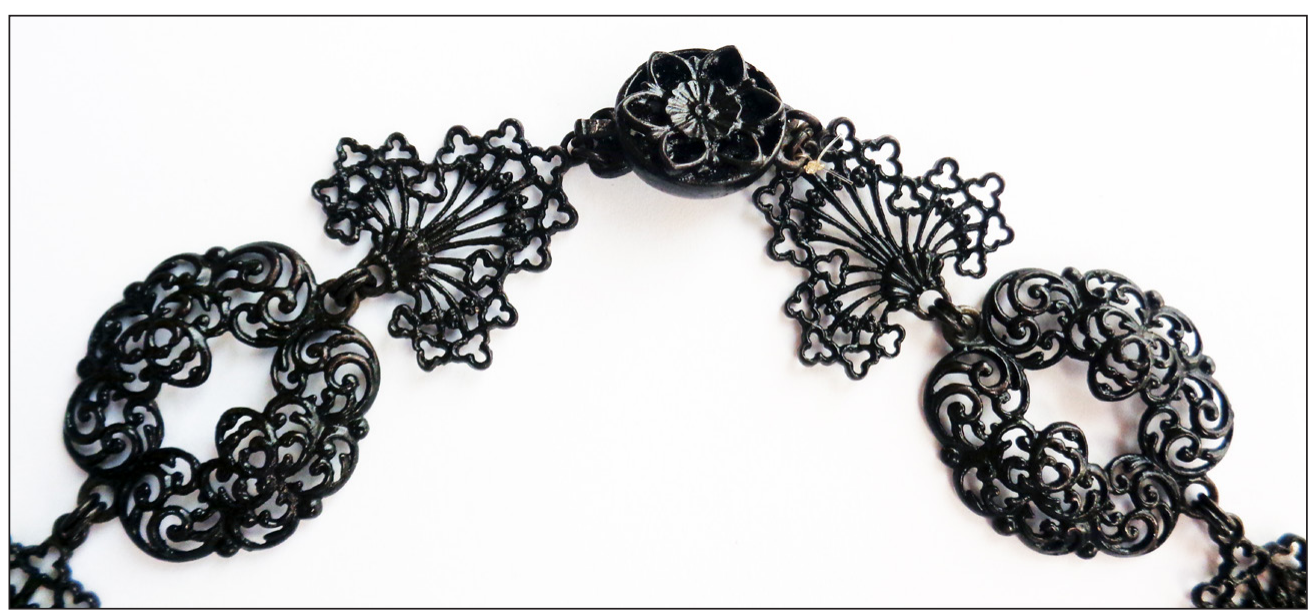

Figura 3 - Finalização do colar com fecho tipo palheta. ${ }^{8}$ Fonte: Acervo do Museu Histórico Nacional. 
A partir de ouro, prata e platina foram feitas joias na tradição de várias sociedades ao longo de, ao menos, 6 mil anos. A estes objetos foram atribuídos diversos sentidos e significados que os mantiveram desejados e cobiçados - sendo também ressignificados com o passar do tempo. De anéis de compromisso, status marital, econômico e social usados por mulheres na Britânia Romana, ${ }^{9}$ às joias de cabelo $^{10}$ do oitocentos, que então foram espaços para expressar afeto, compromisso, saudades e distinção social, podemos afirmar que as sociedades delegaram papéis às joias e, portanto, agência social.

A joia faz parte da vasta lista de itens que compõem a cultura material de várias sociedades e em diferentes cenários históricos. Hoje, entendemos esta como um tipo de adorno pessoal, confeccionado a partir de metais nobres, ${ }^{11}$ que recebe o acréscimo de outros materiais em sua composição, como gemas, ${ }^{12}$ esmaltes, $^{13}$ vidros, madeiras, plásticos etc. É artefato produzido por processos artesanais e/ ou semi-industriais de fabricação, ${ }^{14}$ em peças únicas, em pequena ou grande escala, a partir de novas tecnologias e técnicas convencionais; atendendo às demandas formuladas pelo mercado e pelas transformações nas relações sociais e, portanto, nos sentidos, funções e valores conferidos às coisas materiais.

Adornos pessoais são objetos usados sobre o corpo, que recebem diversos atributos conforme o contexto em que são configurados, conhecidos, reconhecidos e adotados. Hoje classificamos os adornos pessoais pelos aspectos venais e simbólicos em joias, folheados, bijuterias e biojoias. ${ }^{15}$ Os materiais; a qualidade da mão de obra e da produção envolvidas; a forma, a aparência e o vínculo com a moda; e o prestígio da marca são determinantes no posicionamento do adorno pessoal e de suas categorias no mercado e na "lista de desejos" das pessoas.

No século XIX, os adornos pessoais figuraram entre os produtos industriais; foram pensados e criados por artistas, arquitetos, artesãos e pelos pioneiros do design; apresentados em exposições regionais, nacionais e internacionais, ${ }^{16}$ seguindo padrões determinados pelas estruturas e dinâmicas sociais, expressas na moda, nos estilos e movimentos artísticos diversos.

Entre 1804 e o início da segunda metade do oitocentos, pequenos objetos e joias confeccionados em ferro, por fundição em areia, foram desenvolvidos na Prússia ${ }^{17}$ e receberam as denominações Berliner Eisen, Fer de Berlin, Fonte de Berlin e Berlin Iron. ${ }^{18}$ Esses adornos pessoais escuros, vistosos na forma, mas discretos no material e no efeito visual, foram populares e muito usados pela boa sociedade ${ }^{19}$ oitocentista europeia como joias no período de luto aliviado 20 e como itens de moda ao compor a aparência distinta. Passaram a símbolo de nacionalismo, patriotismo e resistência a Napoleão, na Guerra Prussiana de Libertação, entre 1813 e 1815. Sob o lema e a inscrição Gold gab ich für Eisen ("Doei ouro por zios. Na peça central - que denominaremos $\mathrm{A}$-, de tamanho maior que os dois componentes repetidores os quais denominaremos $\mathrm{B}$ e C -, chamam a atenção três elos aparentes em sua borda inferior. Seu desenho é distinto, embora harmônico em relação ao desenho das demais peças. Em cada lado da peça central $(41 \mathrm{~mm}$ x $47 \mathrm{~mm} \times 3,5 \mathrm{~mm}$ ), estão organizadas quatro peças $\mathrm{B}$ (25mm x 28mm x 3,5mm) e cinco peças $C(23 \mathrm{~mm} x$ $23 \mathrm{~mm} \times 3,5 \mathrm{~mm}$ ), igualmente abauladas e recortadas, intercaladas e unidas por elos duplos e contra elos fixados no corpo das peças. A peça $B$ é a segunda em dimensão; tem formato ovalado e contorno formado por dois gomos em composição de volutas; no encontro dos gomos são aparentes elos circulares fixos. A peça C é a terceira em dimensão; tem formato de palma ou leque, triangular, com base maior que topo; tem composição distinta de A e B, pelas linhas em abertura da base para as extremidades, sem volutas; na base e topo possui elos circulares fixos. Comprimento total do objeto: aproximadamente $515 \mathrm{~mm}$. Peso total do objeto: 33g. Não há inscrições.

8. O fecho tipo palheta tem formato circular (14mm x $14 \mathrm{~mm} \times 4 \mathrm{~mm}$ ); a parte "fêmea" do fecho é caixa circular encimada por flor e pequena chapa com furos soldada à base, enquanto a parte "macho" do fecho lingueta confeccionada de chapa - não apresenta ornamentos. Os dois elementos possuem dois pequenos furos para a conexão por elos aos demais componentes.

9. Cf. Santos (2006).

10. Cf. Santos (2014).

11. Metais são substâncias químicas encontradas na natureza, na forma de minerais. Cada metal apresenta 
características físico-químicas próprias, o que lhe confere particularidades e aplicações distintas. Ao longo da história, os metais nobres e tradicionais na joalheria - ouro, prata, platina e alguns metais de seu grupo (rutênio, ródio, paládio, ósmio e irídio) - foram considerados como valiosos, para além das suas propriedades físico-químicas. A estes metais foram atribuídos valores simbólicos e de mercado, que não lhes são imanentes, mas históricos.

12. Gema [do latim gemma]: pedra preciosa; substâncias naturais orgânicas ou inorgânicas, que por suas características intrínsecas (cor, beleza, raridade, dureza e brilho) são utilizadas como adornos pessoais. As gemas podem ser de origem mineral (como a esmeralda), de origem vegetal (o âmbar) e animal (a pérola). "Gema" é a nomenclatura atual para definir as pedras consideradas preciosas, que são usadas na joalheria (INSTITUTO BRASILEIRO DE GEMAS E METAIS PRECIOSOS, 2009; Monteiro, 2004; Schumann, 1990).

13. Esmalte: material cerâmico, formado por substâncias inorgânicas. Como no vidro, a sílica ( $\mathrm{SiO} 2)$ é o componente fundamental do esmalte. Em seu estado normal, o esmalte é transparente e incolor, podendo ser transformado em opaco e colorido pelo acréscimo de óxidos, opacificantes e corantes. O esmalte é usado como decoração, revestimento e proteção para os metais que oxidam. Na esmaltação a quente sobre metais, superfícies inteiras são cobertas ou tem espaços preenchidos por esmaltes com pontos de fusão entre $720^{\circ} \mathrm{C}$ e $800^{\circ} \mathrm{C}$. O processo é artesanal e os metais utilizados no processo são: ouro, prata, cobre e suas ligas (latão, prata ger- ferro") ou Umgetauscht zu des Vaterlandes Wohl ("Trocado pelo bem da Pátria"), homens e mulheres trocaram suas joias de ouro por outras feitas de ferro. Há registros de que em Berlim foram trocados em torno de 160 mil anéis ao longo da campanha. ${ }^{21}$ Com o fim das guerras napoleônicas, a Prússia exportou joias de ferro, já com sentido e valor ressignificados, para todo o mundo.

O ferro (do latim ferrum) - metal resistente, maleável, tenaz e escuro; de fácil oxidação e baixo valor comercial; fundido em fina areia, envernizado e isolado com óleo de linhaça ${ }^{22}$-, foi transformado em produto de moda e em um importante produto manufaturado na Prússia pelas estatais Königleche Eisengiesserei bei Berlin (Real Fundição de Ferro de Berlim), ${ }^{23}$ Gleiwitz e Saynerhütte, e fábricas privadas como as de Johann Conrad Geiss (1771-1846), Alfred Richard Seebaß (1 805-1 884), August Ferdinand Lehmann (1 806-2), Johann Friedrich Gottlieb Müller (1799-?), Simeon Pierre Devaranne (1789-1859) e Albert Anton Meves (1812-2). A criação de fábricas em Gleiwitz, Sayn e Berlim foi iniciativa do Estado prussiano para incentivar o crescimento econômico e industrial nacional, a exemplo do próspero modelo britânico.

A fabricação de joias e objetos decorativos foi a menor parte da produção focada na indústria secundária da época - responsável pela transformação de matéria-prima em produtos de consumo, máquinas industriais, armas e munição. As fábricas foram adaptadas para a fundição de pequenas e delicadas peças que formaram joias. Criadores - como os arquitetos Karl Friedrich Schinkel (17811841); Ludwig Ferdinand Hesse (1795-1876); Friedrich August Stüler (18001865); Carl Heinrich Eduard Knoblauch (1801-1865); Ludwig Persius (18031845); Johann Heinrich Strack (1 805-1880) e os escultores Leonhard Posch (17501831 ); Johann Gotffried Schadow (1764-1850); Christian Friedrich Tieck (17761851 1); Christian Daniel Rauch (1777-1857); Ludwig Wilhelm Wichmann (17881859) -, modelistas, cinzeladores e fundidores prussianos foram responsáveis por formas e composições muito apreciadas e premiadas no oitocentos, inclusive na "Grande Exposição Internacional de Trabalhos Industriais de Todas as Nações" ("The Great Exhibition of the Work of Industry of all Nations"), ocorrida em 1851 e 1862, em Londres. ${ }^{24} \mathrm{Em}$ torno dos anos 1830, as joias de ferro atingiram o auge do reconhecimento e do gosto internacional, e as 27 fundições e manufaturas de Berlim alcançaram a Inglaterra, a França e a Áustria com suas criações. ${ }^{25}$

O ferro ${ }^{26}$ e as tecnologias envolvidas no seu beneficiamento e na produção de artefatos foram atores principais durante o processo da Revolução Industrial e da estratégia de modernização do mundo ocidental, na segunda metade do setecentos e ao longo do oitocentos. $O$ mundo civilizado era o mundo europeu, capitalista e industrial. A Inglaterra era a referência primeira de nação próspera, em veloz crescimento e usufruindo dos benefícios do progresso. Esse progresso 
surgiu embasado em uma nova dinâmica de produção, relações e trabalho - a dinâmica da indústria -, que se expandia, que se diversificava e acelerava a configuração dos novos tempos. Os grandes centros urbanos foram espaços de circulação, implementação e proliferação do novo sistema econômico e produtivo. $\bigcirc$ ferro, o aço ${ }^{27}$ e o vidro passaram a ser as matérias-primas que possibilitaram a rápida multiplicação desses novos modelos de ver, viver e produzir. Hoje, ao pensarmos naquele mundo e em seus vestígios - pontes, estradas de ferro, máquinas e edificações -, percebemos que o conhecimento e o domínio desses materiais e das tecnologias de produção a eles relacionadas foram fundamentais para a construção da modernidade e do mundo entendido, então, como civilizado.

Os horizontes dos homens das ciências e escritores expandiam-se, e estes concebiam um futuro - próspero e até fantástico - no qual as ciências, as máquinas e as tecnologias possibilitariam o que era inimaginável até então. Em Da Terra à Lua (1865), Júlio Verne (1810-1905) nos envolve na fantástica façanha de um projétil de ferro tripulado atingir a Lua. Na ficção, desbravadores e cientistas somaram seus conhecimentos para materializar uma ideia em aventura, e o domínio do ferro viabilizou o experimento.

- Amigos, admito que essa composição deu ótimos resultados [cem partes de cobre, doze partes de estanho e seis partes de latão] - comentou o presidente. - Só que no nosso caso seria muito caro e muito difícil de utilizar. Por isso, acredito que precisamos optar por uma matéria de excelência, mas barata, como o ferro fundido. Concorda comigo, major?

- Plenamente - respondeu Elphiston.

- O ferro fundido custa dez vezes menos do que bronze - retomou Barbicane. - Por ser um material fácil de fundir, rápido de manipular e que se modela com facilidade aos moldes de areia, representa ao mesmo tempo uma economia de tempo e dinheiro. Além disso, é uma matéria de excelência e lembro que durante a guerra, no cerco de Atlanta, cada peça de artilharia de ferro fundido foi disparada mil vezes, de vinte em vinte minutos, sem apresentar problemas. ${ }^{28}$

[...] ○ Comitê decidiu utilizar ferro fundido para erguer a Columbiad, em particular ferro fundido cinzento. De fato, esse metal é mais tenaz, mais dúctil, mais maleável, de fácil alesagem, apropriado para todas as operações de moldagem e, com um tratamento de carvão mineral, apresenta qualidade superior para todas as peças de grande resistência, como canhões, cilindros de máquinas a vapor, prensas hidráulicas etc. ${ }^{29}$

Embora o ferro tenha sido utilizado por diversas culturas desde a Antiguidade, o oitocentos foi o momento em que se buscou conhecer, pesquisar e testar suas características físico-químicas; novas técnicas e tecnologias de produção; manica, alpaca, tombac, bronze) e ferro.

14. Na produção de adornos pessoais, os processos de fabricação podem ser artesanais ou semi-industriais - nesse segmento, o trabalho artesanal está sempre envolvido. Processos de seriação de peças e/ou partes de peças podem ser usados para a reprodução em quantidade de um modelo - produção em escala - ou na montagem de peça única em trabalho artesanal.

15. Cf. Santos (2014).

16. Cf. Gere e Rudoe (2010); Santini e Barbury (2020).

17. O processo de fabricar joias de ferro foi desenvolvido em fundições na Prússia: em Gleiwitz, na Silésia (região entre as atuais Polônia, República Checa e Alemanha); Sayn e Berlim (Alemanha), nos anos 1790. Entretanto, esse tipo de joia e essa tecnologia receberam maior atenção e investimento da Real Fundição de Berlim e de fábricas da iniciativa privada alguns anos depois, em 1804. Cf. Dawes e Davidov (1991); Arenhövel, Schreiber e Vorsteher (1982); Cf.= Untracht (1985).

18. Cf. Arenhövel, Schreiber e Vorsteher, op. cit.; Cf. Evans (1989, p. 170); Cf. Bennett e Mascetti (1999, p. 53-54); Phillips (2006, p. 131, 142).

19. O termo "boa sociedade" traduz características como as da sociedade brasileira, que se fez apresentar e representar por práticas, atitudes, aparência e consumo distintivo. Nesse grupo da boa sociedade, além da classe senhorial e dos políticos, incluímos burgueses - negociantes, bacharéis, profissionais liberais, banqueiros, altos funcionários do Estado e outros, que adotaram um estilo de vida "civilizado". 
Foram homens e mulheres que, além da influência política que exerceram, possuíam poder econômico e prestígio social (Schwarcz, 1999; Vainfas, 2002).

20. O "luto aliviado", ou "meio-luto", segue o período do "luto fechado", que tem duração de doze a 24 meses. Pela etiqueta vitoriana, no luto aliviado, roupas, adornos pessoais e acessórios em outras cores além do preto poderiam ser usadas - como as cores roxo, lavanda, cinza, azul-marinho e marrom. No período vitoriano, o uso de enfeites em roupas (bordados e apliques) e adornos pessoais escuros foi permitido, feitos de azeviche, azeviche francês, ônix e cristais (Curl, 2001; Morley, 1971; Schmitt, 2010; Taylor, 1983). Sobre luto e joias de afeto e saudade: Cf. Santos, I. (2009, 2014) e Art of Mourning ([20-]).

21. Cf. Phillips (2000).

22. No catálogo Eisen statt gold, por Arenhövel, Schreiber e Vorsteher (op. cit.), são mencionadas duas receitas de verniz isolante para as joias de ferro: 1 Verniz de Gleiwitz: 1,1L de óleo de linhaça cru $+233 \mathrm{~g}$ de resina de Borgonha ou asfalto $+87,6 \mathrm{~g}$ de óxido de chumbo $\mathrm{PbO}+116 \mathrm{~g}$ de fuligem; 2 Verniz de Berlim: 1,1L de óleo de linhaça + 14,6 g de óxido de chumbo Pb3O4 (Minium) + 14,6 g de $\mathrm{PbO}$ (tradução por Achim Feller e Profs. Cesar Roberto de Farias Azevedo e Fernando José Gomes Landgraf, da Escola Politécnica da USP).

23. A fundação estimada da Real Fundição de Ferro de Berlim é do ano de 1804 , e suas atividades foram encerradas em 1874. Elisabeth Bartel (curadora da coleção de objetos de ferro do Stadmuseum Berlin) afirma que, desde 1789 , houve ações os limites de seu desempenho e o aplicar em diversos fins e projetos - ferramentas, instrumentos, equipamentos e máquinas; sistemas de engenharia; transportes; estruturas arquitetônicas; armamentos; objetos de arte; artigos de consumo etc. - , que oscilaram entre realizações pragmáticas e fantasiosas.

P Palácio de Cristal - edifício projetado por Joseph Paxton, que abrigou a Primeira Exposição Internacional de Trabalhos Industriais de Todas as Nações, em 1851, em Hyde Park (Londres) - foi construído em 5 meses pelas mãos de 2260 trabalhadores e expressou o progresso, a civilização e o gigantismo industrial britânicos em estrutura pré-fabricada, erguida a partir de 4.082 toneladas de ferro e 295.655 folhas de vidro, em 563m de comprimento e $33 \mathrm{~m}$ de altura. No interior do opulento espaço de exibições, foi organizado o Pavilhão das Máquinas (Setor $21^{30}$, que expôs prensas hidráulicas, martelos a vapor, locomotivas, máquinas de fiar algodão, turbinas a vapor, máquinas de impressão e outras maravilhas da engenharia, do conhecimento científico e do domínio tecnológico e do ferro.

Joias confeccionadas em aço e, posteriormente, em ferro foram novidades para a boa sociedade britânica e francesa no final da segunda metade do século $X V I I I .{ }^{31}$ A utilização desses materiais na construção de joias nos faz estranhar que, em algum momento da história, que não na atualidade, elites de sociedades modelares pudessem desejar, usar, atribuir e reconhecer valor em tais objetos. $\bigcirc$ aço e o ferro ofereceram aos homens e mulheres, observadores do que havia de mais distintivo e moderno no seu tempo, efeito visual e táctil diferente ao das joias tradicionais. Embora semelhantes no uso, na forma, na composição (temática, dimensões, proporções e volumes) e nos ornamentos, as joias de ferro e aço eram próprias por sua fabricação, aparência e pelas características de seus insumos. Estas não foram concebidas para imitar os efeitos e os materiais das joias tradicionais.

Se, em um primeiro momento, as joias de ferro e aço foram pouco acessíveis e expressavam distinção social, com o decorrer do tempo e o aumento do volume de produção, passaram a peças comuns e perderam o apelo de item de moda. A Inglaterra produziu artefatos de aço desde o século XVI. No século XVIII, as joias de aço facetado e polido foram reconhecidas pela produção de Woodstock, em Oxfordshire, ${ }^{32}$ Wolverhampton e Birmingham. ${ }^{33}$ Receberam acréscimos de outros metais, gemas - com destaque para as marcassitas ${ }^{34}$-, elementos decorativos de cerâmica Wedgwood, intaglios ${ }^{35}$ e camafeus em pasta de vidro por James Tassie. No século XIX, a produção britânica diminuiu diante da concorrência da produção francesa, prussiana, austríaca e sueca. ${ }^{36,37}$

As fundições em ferro se estabeleceram na Prússia no século XVII e no início do século XIX gozavam de grande prestígio pela qualidade e precisão de seu trabalho, tanto em objetos de pequenas dimensões - alfinetes; anéis; botões; 
brincos; broches; colares; correntes; crucifixos; diademas; fivelas; insígnias; medalhas e medalhões; ordens; passadores; pendentes; pentes; presilhas; pulseiras; sinetes; tiaras; caixinhas de rapé; chaves de clavicórdio ou de relógio; bolsinhas; monóculos; leques (Figura 4) e lupas - como nos de grandes e médias dimensões - monumentos; esculturas; gradis e elementos arquitetônicos; mobiliário e objetos decorativos, como caixas para joias (Figura 5); castiçais; espevitadeiras; molduras; pequenas placas com relevos comemorativos de Ano Novo (Neujahrplaketten) ou retratos; pesos de papel; porta relógios; tinteiros; vasos etc. ${ }^{38}$

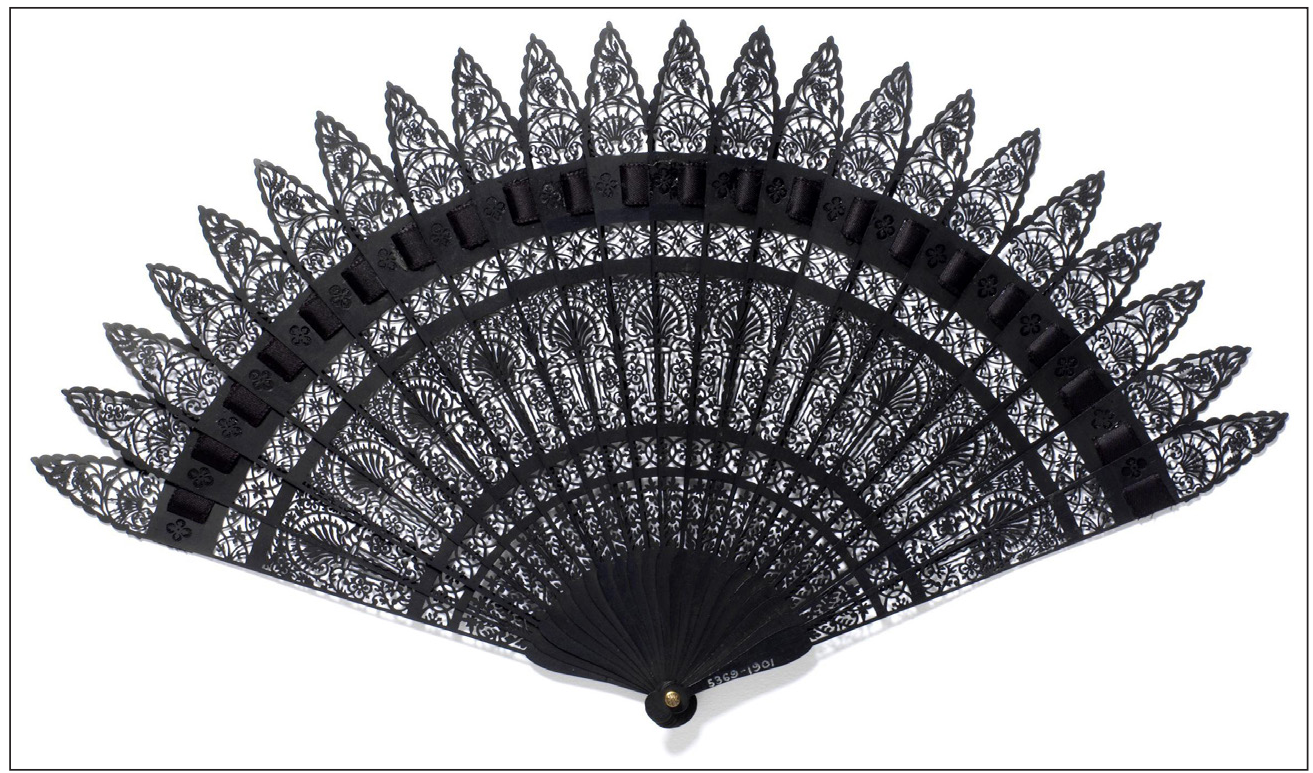

Figura 4 - Leque com varetas em ferro fundido, unidas por fita de cetim e rebite de latão; origem atribuída a Edward Schott, Ilsenburg am Harz, Alemanha, c. 1862. Fonte: Acervo do Victoria and Albert Museum, Londres. ${ }^{39}$

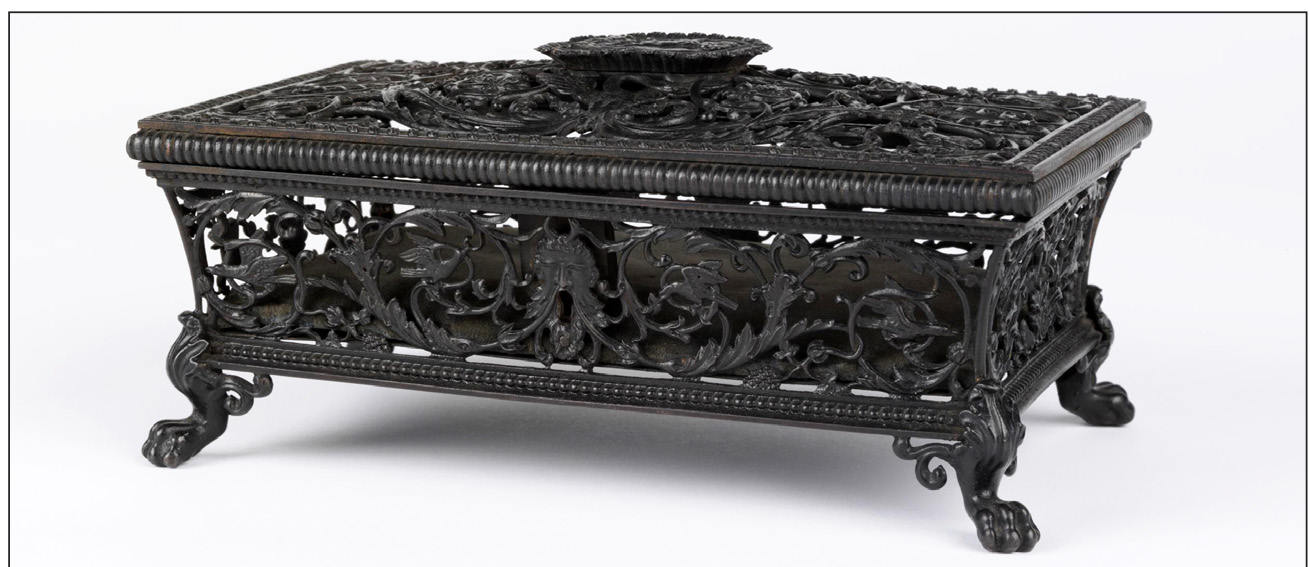

Figura 5 - Caixa para joias em ferro fundido, com origem atribuída à Alemanha, c. 1815-1830. Fonte: Acervo do Victoria and Albert Museum, Londres. ${ }^{40}$ para a fundação de uma fundição de ferro estatal em Berlim, "no estilo inglês", segundo o Ministro da Mineração Friedrich Anton Freiherr von Heinitz e o conselheiro Friedrich Wilhelm Graf von Reden. A iniciativa materializou-se com Gleiwitz (na Alta Silésia, atual Polônia), que iniciou suas operações em 1796.

24. Simeon Pierre Devaranne, reconhecido por sua variada produção de joias de ferro, expôs seus produtos na "Primeira Exposição Industrial de Berlim", em 1822; na "Segunda Exposição Industrial de Berlim", em 1827; na "Primeira Exposição Industrial Alemã", em Mainz, em 1842, e na "Grande Exposição Internacional de Trabalhos Industriais de Todas as Nações", em Londres, em 1851. Edward Schott criou um leque de ferro, para demonstrar finura que poderia atingir a fundição do ferro, e o expôs na Grande Exposição Internacional de Trabalhos Industriais de Todas as $\mathrm{Na}$ ções, em Londres, em 1862 (VICTORIA AND ALBERT MUSEUM, 2005).

25. Cf. Bury (1982); Clifford (1971); Gere e Rudoe op. cit..

26. Símbolo: Fe. Ponto de fusão: $1536^{\circ} \mathrm{C}$. "O ferro que constitui a base de todos os materiais conhecidos como metálicos ferrosos, pode ser obtido, em quantidades comercialmente aceitáveis, a partir dos seguintes minérios: a hematita, a limonita a magnetita ou a siderita. No Brasil, a obtenção de aço e de ferro fundido dá-se por meio do uso da hematita. [...] Para transformar a hematite em matéria-prima industrial é necessário submetê-la ao processo siderúrgico que em suma permite a obtenção da liga constituída de ferro e carbono (ferro fundido e suas ligas) e posteriores deriva- 
ções em produtos siderúrgicos" Lima (2006, p. 39). Cf. Kliuga (2009, p. 30-31); Cf. Untracht (1985).

27. Aço é uma "liga de ferro e carbono na qual o percentual de carbono por peso não ultrapass[a] o limite de 2\%" (Lima, op. cit., p. 43).

28. Verne (2018, p. 75)

29. Ibid., p. 131.

30. Na Grande Exposição Internacional de Trabalhos Industriais de Todas as Nações, em Hyde Park (Londres, Inglaterra), em 1851, os espaços de exposição foram divididos em: matéria-prima (raw materials), maquinaria (machinery), manufaturas (manufactures) - setor dividido em 19 classes, no qual foi alocado o segmento de joalheria -, e Belas Artes (fine arts).

31. Além do aço e do ferro, $o$ alumínio também foi usado na construção de joias em meados do século XIX. O alumínio - isolado em 1824 pelo dinamarquês Hans Christian Orsted e com método de produção industrial descoberto no início de 1854 pelo químico francês M. H. St. Claire Devillee - foi mais valorizado que o ouro durante as duas décadas seguintes. Considerado um metal raro, despertava curiosidade, encantando por sua leveza e pelo fato de não oxidar. Em meados do oitocentos, o joalheiro francês Honoré Bourdoncle passou a usá-lo experimentalmente junto com ouro de alto teor na confecção de conjuntos de joias com formas a partir da arquitetura gótica. Joias de alumínio foram expostas na Grande Exposição Internacional de Trabalhos Industriais de Todas as Nações, em 1851, mas o grande sucesso ocorreu na "Exposition Universelle des Produits de l'Agriculture, de l'Industrie et des Beaux-
Datam de 1804 os primeiros exemplos de joias de ferro de Berlim. Algumas empresas parisienses e austríacas, após os anos 1820 e 1830, também confeccionaram joias de ferro segundo os padrões prussianos, o que dificulta a identificação da origem das peças não assinadas disponíveis hoje nas coleções de museus ${ }^{41}$ ou em leilões.

Quanto à composição, as joias de ferro são divididas em três fases, possuindo características neoclássicas (entre 1804 e 1815), naturalistas (entre 1815 e 1830) ou neogóticas (entre 1830 e 1850). Embora seja possível observar essa distinção, existem peças em que componentes dos três períodos se misturam, pois as novas composições e propostas gráficas surgiram, mas as anteriores seguiram em circulação.

As características neoclássicas das composições foram expressas em camafeus; molduras florais; folhas de parreira e de acanto; palmas, cenas e personagens mitológicos; figuras e elementos decorativos clássicos; liras; flores (rosas e lírios) (Figura 6). Já as composições naturalistas apresentavam perfis de rostos femininos; flores; frutos e folhagens vaporosas (realistas ou estilizadas); volutas; símbolos das virtudes teológicas, como a cruz, símbolo da fé; a âncora, símbolo da esperança; o coração, símbolo da compaixão (Figura 7). Enquanto isso, as composições neogóticas traziam elementos arquitetônicos - como trifólios, quadrifólios, arcos de ogiva, pórticos e contrafortes pontiagudos, florões e rosáceas, gradis e forjas -, parreiras, flores (rosas, lírio e flor de lis) e mãos que seguram elos ou finalizam correntes (Figura 8). Todas essas características foram elaboradas e combinadas em algumas ocasiões.

O colar do Museu Histórico Nacional é um exemplar da segunda fase de configuração das joias de ferro - a naturalista. As linhas curvas e vaporosas, intercaladas por espaços vazios, formam contornos de palmas, flores e follhas estilizadas (Figuras 1, 2 e 3).
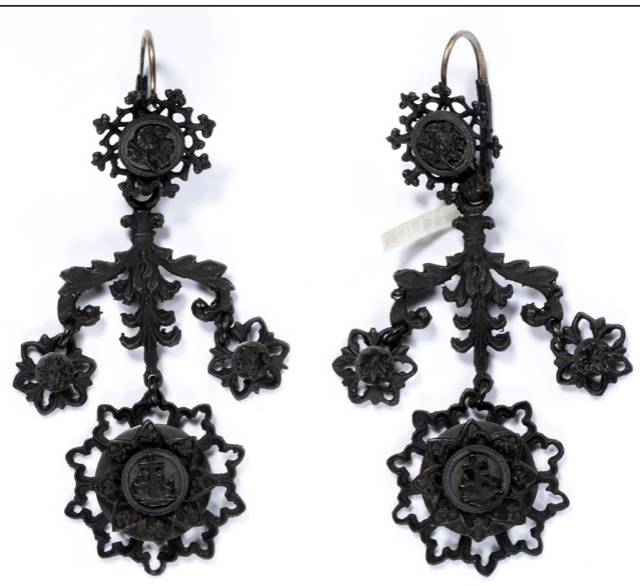

Figura 6 - Par de brincos, com origem atribuída a Berlim (c. 1830) e características neoclássicas (medalhas camafeus centrais com ícones das virtudes teológicas: cruz, âncora e coração). Fonte: Acervo do Victoria and Albert Museum, Londres. ${ }^{42}$ 


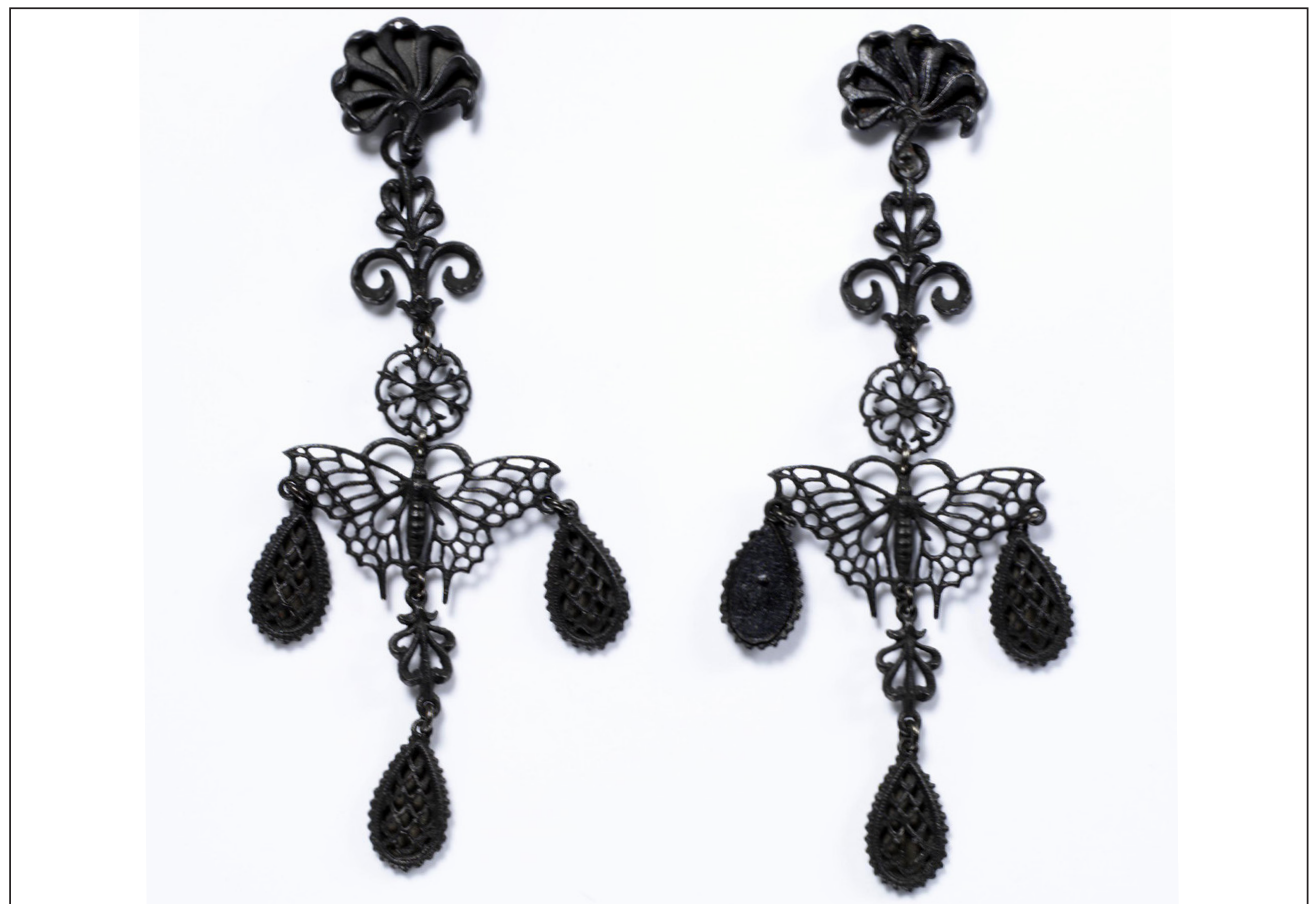

Figura 7 - Par de brincos, de Simeon Pierre Devaranne, com origem atribuída a Berlim (c. 18 1 5-51) e características naturalistas (borboletas e ornamentos florais estilizados). Fonte: Victoria and Albert Museum, Londres. ${ }^{43}$

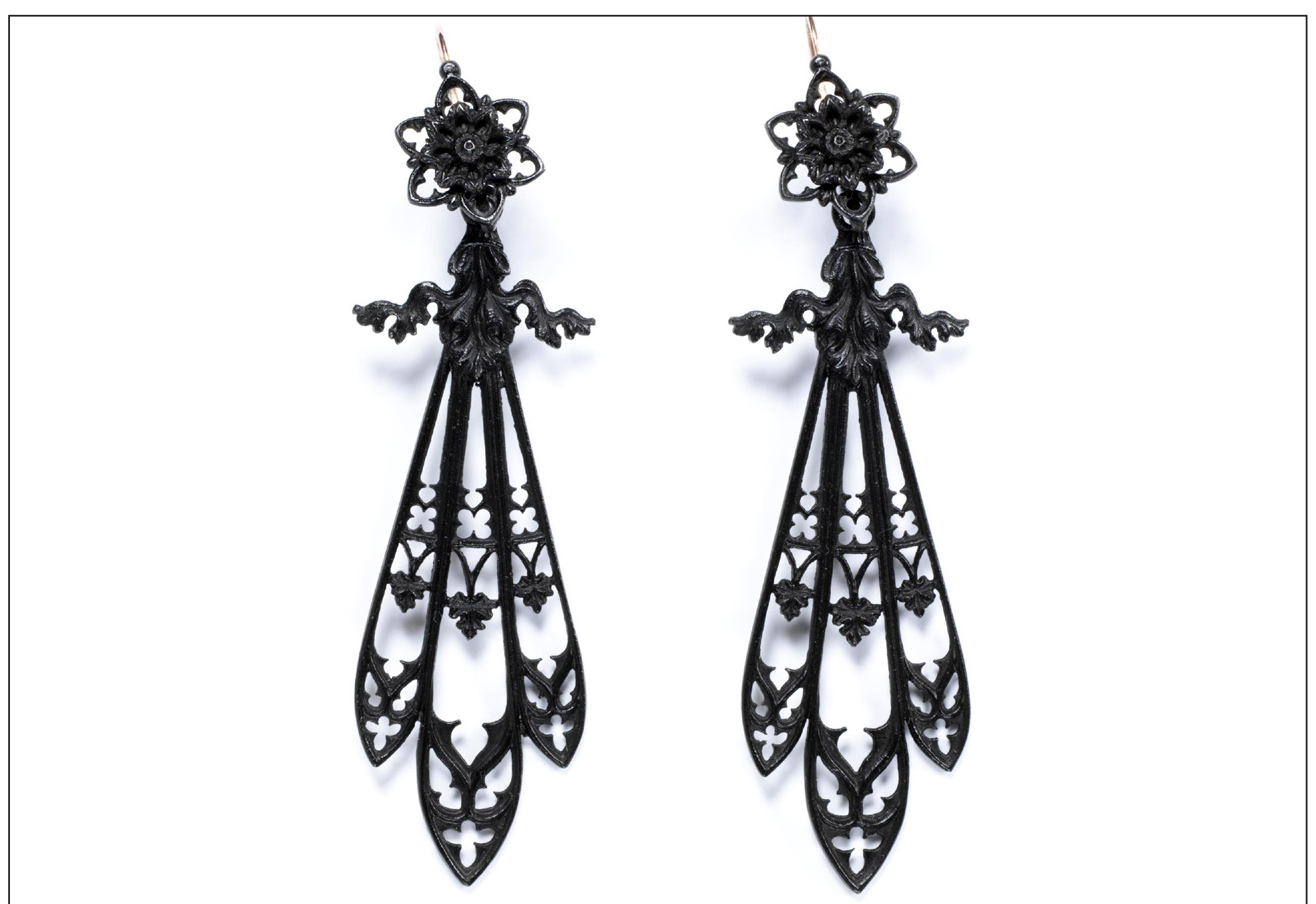

Figura 8 - Par de brincos, com origem atribuída a Berlim (c. 1830) e características neogóticas (detalhes arquitetônicos góticos estilizados). Fonte: Victoria and Albert Museum, Londres. ${ }^{44}$
-Arts" ("Exposição Universal de Produtos da Agricultura, da Indústria e das Belas Artes") de Paris, em 1855 (Gere; Rudoe, op. cit.) e em 1867 (Dawes; Davidov, op. cit.). Já as peças do joalheiro Charles Henry Villemon foram apreciadas, a partir de 1860 , pela gravação de desenhos florais.

32. "Woodstock is a small town which however is renowned all over England for fine workmanship in steel. The Woodstock workmanship is much preferred to that of Salisbury and it is not unusual to find steel scissors, buckles, watch chains etc. [...] the best goods in London come from Woodstock" (Kielmanself, 1761 apud Clifford,op. cit., p. 14).

33. Steel toys foi o termo usado para significar chatelaines, joias, correntes para relógios, tesouras, fivelas para roupas e sapatos confeccionados em aço. No século XVIII, a moda ditava para a joalheria tradicional diamantes lapidados, então o aço facetado e polido imitou o brilho e a luz dos diamantes. Na Inglaterra, em Birmingham, destacou-se a produção do industrial Matthew Boulton (1728-1809) (Matthew Boulton's Soho Works), em Londres Thornhill \& Co. (1810-1912) e Joseph Bank Durham.

34. Cf. Instituto Brasileiro de Gemas e Metais Preciosos, op. cit.

35. Intaglio: palavra italiana, em português entalho, que significa o processo em que incisões ou rebaixos decorativos são feitos em superfícies de pedras e metais.

36. "Swedish steel was famous already in the 18th century and was used in the continental jewellery industry. In Finspångs bruk in Sweden (the Finspång ironworks/foundry), iron jewellery, statues etc. were cas- 
ted at the end of the $1820 \mathrm{~s}$, until 1890. Carl Johan Wilhelm Mertens (born 1802 in Berlin) worked for 6 years in Berlin, and then a lifetime at Finspångs bruk, bringing skills and designs with him. The objects were very popular during the first two decades, at first by the society, even the Royal family, but during time more common and sold to many other customers in Sweden. The objects from Finspång were not stamped, so it's hard to know where they are made, Finspång or Berlin” (Breve apresentação da joalheria em aço e ferro na Suécia, contida em mensagem de Helen Lindroth - curadora do Nordiska Museet, em Estocolmo -, recebida por Irina Aragão dos Santos em 27 de fevereiro de 2019).

37. Cf. Bury (op. cit.) e Clifford (op. cit.).

38. Cf. Arenhövel, Screiber e Vorsteher (op. cit.) e Clifford (op. cit.).

39. Victoria and Albert $\mathrm{Mu}-$ seum (2019).

40. Ibid.

41. As joias de ferro da empresa de Johann Conrad Geiss foram assinadas no verso com "Geiss a Berlin" - Cf. Victoria and Albert Museum (2012). Já as joias de Simeon Pierre Devaranne foram assinadas com "Deveranne Ac. Künstl a Berlin" (vide fivela Ref. 1978,1002.1044, acervo do British Museum, em Londres. Disponível em: < https://bit. ly/3bSudgE $>$

42. Victoria and Albert Museum (2019).

43. Ibid.

44. Ibid.

45. Museus que disponibilizam busca virtual em coleções: MAK - Österreichis-
Atualmente, há inúmeros exemplares de ferro nos museus que têm joalheria em seu acervo. Para o presente trabalho, foram consultados acervos com acesso virtual, ${ }^{45} \mathrm{em}$ reservas técnicas e em exposições no Victoria and Albert Museum (Museu Victoria e Albert) (47 peças) e no British Museum (Museu Britânico) (1 1 peças), em Londres; no Musée Le Secq des Tournelles (Museu Le Secq de Tournelles) (55 peças), ${ }^{46}$ em Roven (França). Além das instituições que cuidam das peças históricas, as páginas virtuais de leiloeiros e negociantes de joias estrangeiros ${ }^{47}$ são fontes interessantes para observar e reiterar o potencial de mercadoria de todo objeto e desenhar sua biografia social, conforme sugerido por lgor Kopytoff. ${ }^{48} \mathrm{Ao}$ resgatarmos trajetórias de vida de artefatos, seus "detalhes biográficos revelam um emaranhado de julgamentos estéticos, históricos e mesmo políticos, e de convicções e valores que moldam as nossas atitudes" $49 \mathrm{em}$ sociedade. Que razões e disposições dotaram as joias de ferro de atributos, para que hoje fizessem parte tanto de acervos de museus e coleções particulares como de leilões de objetos valiosos do passado? $\bigcirc$ que as torna singulares - não mercadorias - e o que as torna mercadorias? Neste desafio, podemos compreender situações que desencadearam as transformações no objeto e na sociedade que o pensou, elaborou, produziu, usou, the deu vida e agência dentro das dinâmicas históricas. Enquanto sacralizados pelo status de objetos museológicos e testemunhas do passado, os objetos em museus não têm preço; mas, como lotes ou itens disponíveis em leilões ou em sites que oferecem artigos históricos, estes são avaliados, precificados e se apresentam prontos para passar às mãos de quem os pagar.

Mas, e o colar creditado à Real Fábrica de Ferro São João do Ipanema, presenteado à Dona Teresa Cristina? Após a leitura de documentos ${ }^{50} \mathrm{e}$ textos sobre a Fábrica, não foi encontrada menção ao colar de ferro - embora não tenham se esgotado as possibilidades de fontes para este trabalho. Não há menção à sua confecção ou importação pela São João do lpanema, assim como não há menção ao ato de presentear a Imperatriz ou ao uso do colar pela Imperatriz. Também não há vestígios do percurso do colar da casa real ao doador - Sr. R. de Freitas Lima, citado no termo de doação (Processo 15/1927), do Museu Histórico Nacional ou do percurso da peça até o Museu. Mas, por que seria interessante a ligação da Real Fábrica de Ferro São João do Ipanema com o colar de ferro e com a Imperatriz, informada na ficha catalográfica do objeto?

No capítulo "Artes e indústria", da obra Formação do Brasil Contemporâneo, Caio Prado Júnior ${ }^{51}$ dedica modesta revisão da produção colonial às artes e à indústria no Brasil, que atribui à "insignificante atividade de elaborar a matéria-prima" em mercadorias naquele período. Argumenta que a inexpressiva produção dos ofícios mecânicos ocorreu de forma distinta nos centros urbanos e na zona rural - nesta, a 
produção esteve vinculada às economias da mineração e da agricultura. Observa que pequena siderurgia foi montada em Minas Gerais para consumo interno, diante da ocorrência de minério de ferro, o que fomentou a autonomia dos domínios rurais em suas demandas cotidianas. Nessa dinâmica, podemos localizar o embrião da indústria futura, que receberá maior atenção no século XIX, quando o Brasil passa a gozar do status de Reino Unido e não mais de colônia portuguesa. Então, a mão de obra não especializada não atendeu às demandas do mundo industrial e foi necessária a contratação de especialistas estrangeiros para beneficiar a matéria-prima e para configurar, orientar, gerenciar e produzir artefatos industrializados.

É importante ressaltar que as técnicas e os instrumentos de mineração adotados no Brasil colonial, se comparados aos padrões europeus, eram rudimentares, improvisados e primitivos. Na mineração do ouro, inúmeros relatos, estudos e textos ${ }^{52}$ reiteram a prática e a experiência cotidiana, o acerto e o erro como balizadores da extração do mineral. Essa atividade foi possível no período colonial, porque o ouro aflorou e esteve exposto à superfície, nos depósitos aluviais recentes, e não nas profundezas de terras brasileiras.

As rochas matrizes são entre nós de pequeno vulto e pobres em teor metálico. Exploram-se inicialmente só aqueles depósitos: passou-se em sucessão, e na medida em que se foram respectivamente esgotando, dos depósitos mais recentes e superficiais, os veios, contidos no leito dos rios - cujas areias ou cascalhos eram às vezes tão ricos que dispensavam até a bateia, catando-se à mão pepitas de ouro -, aos mais antigos e por isso mais profundos; os tabuleiros, na margem contígua; as grupiaras, já a meia encosta. [...] Mas quando se teve de atacar as rochas matrizes, a situação mudou de figura. [...] nas rochas sãs, cuja dureza - trata-se de quartzos, pirites, itabiritos e outras rochas extremamente compactas tornava-se obstáculo à técnica rudimentar dos mineradores da colônia. ${ }^{53}$

Após cem anos de ininterrupta mineração, a escassez do ouro foi determinada pela extração violenta e insaciável nas lavras e leitos de rios. Fez-se necessário investimento, método e conhecimento especializados e o uso de técnicas e tecnologias desenvolvidas por engenheiros europeus na extração em minas profundas, para que a prospecção de minerais fosse retomada. Essa avaliação e a contratação de especialista estrangeiro - o geólogo, engenheiro e naturalista barão Wilhelm Ludwig von Eschwege (1777-1855) -, em 1809, aconteceu justamente quando a corrida e a abundância do ouro cessaram.

A produção de ferro na região de Sorocaba-SP, segundo Müller e Oliveira, ${ }^{54}$ teve início em 1590, por iniciativa do rico comerciante português D. Affonso Sardinha. A estrutura de Sardinha passou por diferentes administrações e teve suas atividades encerradas em 1629. Em 1770, Domingos Ferreira Pereira montou outra fábrica de ches Museum für angewandte Kunst / Gegenwartskunst, em Viena (63 exemplares); Stadtmuseum Berlin (150 exemplares citados em acervo, 28 disponíveis on-line); Nordiska Museet, em Estocolmo (90 exemplares); Birmingham Museum (dois exemplares disponíveis online); Musée de Arts Décoratifs (seis exemplares disponíveis on-line), em Paris; Metropolitan Museum of Arts (sete exemplares disponíveis on-line), em Nova York. Museus citados na bibliografia com joias de ferro em seus acervos: Stiftung Preussische Schlösser und Gärten Berlin-Brandenburg (entre os 850 objetos decorativos de ferro prussiano).

46. O Musée Le Secq des Tournelles foi fundado em 1921, na igreja gótica Saint-Laurent. Sua coleção, iniciada em 1865 pelo pintor francês Jean-Henri Le Secq des Tournelles (1818-1882), é dedicada aos artefatos de ferro, desde o século $\mathrm{V}$ ao início do século XX. É grande o seu acervo de objetos provenientes das fábricas de Berlim. São 157 objetos em pequena escala (dimensão até $160 \mathrm{~mm}$ ): 57 joias de ferro (entre anéis; brincos; broches; pendentes; colares; pulseiras; diademas; tiaras; correntes; alfinete; clipe; presilhas; fivelas; crucifixos e partes), 32 acessórios (monóculos pendentes; pinça pendente de chatelaine; medalhões e chaves de relógios) e 68 objetos diversos (peso de papel; esculturas; pia de água benta; pratos; castiçais; molduras; isqueiros; caixinhas e cofres; placas com relevos; tinteiro; vaso; porta-joias; porta-relógio; puxador de sinetas; suporte para bolsas).

47. Foi consultado o site 1stDibs, fundado por Michael Bruno, negociante de objetos de arte e de luxo, com escritório em Nova York. Na página estavam 
disponíveis 20 joias de ferro, em ótimo estado de conservação, com preços entre US $\$ 3.600$ e US $\$ 16.800$ (1STDIBS, [20-]).

48. Kopytoff (2008).

49. Ibid., p. 93.

50. Entre os documentos consultados estão o diário de Dona Teresa Cristina; o inventário dos bens que foram a leilão após a partida da família real em 1889; o inventário das joias de Dona Teresa Cristina, em 1887; registros da Real Fábrica de Ferro São João do Ipanema; periódicos publicados entre 1845 e 1889, como o Jornal do Commercio e o Correio Paulistano - que data de 17 de outubro de 1886.

51. Prado Júnior (2011). Cf. Franco (2005).

52. Boxer (2000), Dean (1996), Figueiredo (2011) e Prado Júnior (op. cit.).

53. Prado Júnior, op. cit., p. 178. Grifos do autor.

54. Müller e Oliveira (1990).

55. Ibid., p. 1249.

56. "O ferro fundido é, em geral, destinado aos processos de fundição (predominante) [...], a exemplo do aço, pode ser ligado a outros elementos metálicos ou não metálicos, com o intuito de melhorar suas propriedades e possibilitar sua utilização em aplicações específicas. Assim [...] os lingotes de ferro fundido não ligado, obtidos no processo siderúrgico, são submetidos a um processo de fundição juntamente com os seguintes elementos: carbono, silício, enxofre, manganês e fósforo em proporções adequadas ao desempenho esperado do material" (Lima, op. cit., p. 41).

57. Müller e Oliveira, op. cit., p. 1250 . ferro na localidade, mas o empreendimento teve vida curta. Um ano após a venda da fábrica para o Capitão Victoriano José Sentena, em 1776, suas atividades foram interrompidas, pois a Corte não concedeu novo Alvará de licença para funcionamento. A assinatura do Alvará de janeiro de 1785 por D. Maria I, que proibia qualquer atividade manufatureira na colônia, direcionou a economia da região e do empreendimento para a produção açucareira. Somente após a transferência da Corte Portuguesa para o Brasil, em 1808, medidas econômicas e políticas foram cambiadas:

[...] destacam-se a abertura dos portos brasileiros ao comércio com outras nações; a revogação do Alvará de 1785, a criação do Banco do Brasil e de incentivos diretos à produção manufatureira como a distribuição de prêmios de loterias as manufaturas e a isenção de direitos alfandegários às matérias-primas necessárias à produção interna. ${ }^{55}$

Em 1815, o Brasil foi elevado à categoria de Reino Unido com o Reino de Portugal e Algarve. Foram traçadas bases para a sua autonomia administrativa e emergiu o interesse em "promover o crescimento das manufaturas no Brasil, que estimulou a organização de forjas". 56

Em Sorocaba, os primeiros passos em direção ao reaparecimento da metalurgia foram dados em 1810, quando o Príncipe Regente D. João, reconhecendo que não havia nenhuma mina de ferro sendo explorada em Sorocaba, e, considerando ser "de suma importância criar no Brasil estabelecimentos de minas de ferro na maior extensão possível, que pudessem dar ferro e servir de base às preciosas manufaturas do mesmo metal não só para consumo no Brasil, mas também para exportação. ${ }^{57}$

Já em 1809, as intenções de fomentar o crescimento econômico da região e do Reino resultaram na assinatura de contrato de prestação de serviços entre o empresário metalurgista sueco Carl Gustav Hedberg e a Coroa Portuguesa. A Hedberg coube a tarefa de "construir e organizar minas de ferro, cobre, prata e ouro" e erguer um dos altos-fornos ${ }^{58}$ do projeto siderúrgico de Dom João. Em 4 de dezembro de 1810, por Carta Régia, foi fundada a Fábrica de Ferro da Villa de Sorocaba. Em 181 1, foram iniciadas as obras de construção da Fábrica, que, ainda sob gestão de Hedberg, entre 1811 e 1814, passaria à nova razão social: Real Fábrica São João do Ypanema. Já sob direção de Friedrich Ludwig Wilhelm Varnhagen, de 1815 a 1821, operários e especialistas em siderurgia prussianos chegaram ao Brasil: 
Ao contratar os técnicos alemães, Varnhagen sonhava com a construção de uma fábrica de grande porte capaz de atender a demanda de ferro proveniente de estabelecimentos fabris existentes nas províncias vizinha, do exército real e de grande número de engenhos de açúcar, localizados ao redor da Fábrica. Para tanto, seriam produzidos em Ypanema desde implementos agrícolas - máquinas, pás, enxadas, caldeirões, tachos, cilindros etc. - até armas e outros artefatos militares. ${ }^{59}$

Ao longo do século XIX, a Fábrica do Ipanema operou alternando períodos de eficiência e produção insignificante ou abandono, sendo definitivamente fechada pelo governo republicano em 1895.60 $\bigcirc$ dinheiro público investido na construção, manutenção e desenvolvimento da Fábrica fez parte do amplo projeto de tornar o Brasil uma nação próspera, autossuficiente e moderna, que objetivava o progresso e os modelos civilizados europeus. São João do lpanema foi a "única siderúrgica de grande porte mantida pelo Governo no país durante o século XIX"bl e esteve associada ao crescimento econômico e à defesa do território nacional.

Apesar de ter acumulado avultado déficit ao longo de sua história, o estabelecimento foi importante produtor de ferro fundido em barras e de diversas peças do mesmo metal como panelas, tachos, pregos, engrenagens, cilindros e máquinas de beneficiar o café. Fabricou também munição de diversos calibres Seus produtos eram consumidos por particulares e pelo próprio Governo Imperial.62

D. Pedro II visitou a Real Fábrica São João do lpanema quatro vezes. A primeira vez foi em abril de 1846, quando conheceu o portão fundido em ferro em homenagem a sua maioridade (atingida em 1841) - embora conste na ficha catalográfica do colar de ferro do Museu Histórico Nacional que D. Teresa Cristina visitou a Fábrica, Almeida ${ }^{63}$ afirma que nesta ocasião a Imperatriz permaneceu em São Paulo. A segunda visita foi realizada em agosto de 1875, para a inauguração da Estrada de Ferro Sorocabana - nesta ocasião, D. Pedro II recebeu uma cópia em ferro da coroa imperial de D. João VI (Figura 9), que consta no inventário do $5^{\circ}$ leilão do Paço de São Cristóvão, dos bens da família imperial, ocorrido em 12 de setembro de 1890. ${ }^{64}$ A terceira visita de D. Pedro II ocorreu em outubro de 1878, acompanhado de D. Teresa Cristina. Já a quarta visita à Fábrica foi em novembro de 1886, também acompanhado pela Imperatriz, para a inauguração de um conjunto de oficinas novas - para esta ocasião uma placa comemorativa foi executada. ${ }^{65}$
58. No período, "o alto-forno era o principal processo mundial de produção de ferro [...] A fusão do ferro metálico nos altos-fornos explica-se, em linhas gerais, pelo aumento da altura do forno. Carregados com camadas sucessivas de carvão, minério e fundentes, fornos mais altos permitem que o ferro permaneça por mais tempo em contato com o monóxido de carbono (CO). Desse modo, o ferro absorve até $4 \%$ de carbono e seu ponto de fusão passa a ocorrer abaixo de $1200^{\circ} \mathrm{C}$, resultando em ferro líquido. Esse ferro destinava-se à produção de peças fundidas, como canhões, moendas, panelas ou era solidificado em grandes barras ou 'pães' de gusa, que eram depois refinadas para obtenção de ferro dúctil" Landgraf (2014, p. 5). As joias de ferro, por suas características, devem ter sido fabricadas com o ferro fundido cinzento (ferro $+4 \%$ de carbono $+1 \%$ de silício $+0,4 \%$ de fósforo), que tem por característica maior fundibilidade e elevada fluidez - assim, possibilita a formação de peças com geometria complexa, razoável resistência à corrosão, resistência ao desgaste e baixo custo.

59. Müller e Oliveira, op cit., p. 1256.

60. Cf. Santos, N. (2009). A Fábrica era localizada no município de Iperó, entre Sorocaba e Boituva, a aproximadamente $125 \mathrm{~km}$ da cidade de São Paulo. O complexo construído foi tombado pelo Instituto Histórico e Artístico Nacional (Iphan) em 1964. Encontra-se dentro de uma área de proteção ambiental do Ibama (Instituto Brasileiro do Meio Ambiente e dos Recursos Naturais Renováveis), com 5.069,73 hectares, pertencente à Floresta Nacional de Ipanema, criada em 1992 para preservar 
e conservar um dos maiores fragmentos de Mata Atlântica do estado de São Paulo, áreas de cerrado, várzea e ecossistemas associados (INSTITUTO CHICO MENDES DE CONSERVAÇÃO DA BIODIVERSIDADE, 2012). Cf. Landgraf (1994 e 2016) e Lobo (2016).

61. Müller e Oliveira (1990, p. 14).

62. Ibid., p. 19.

63. Almeida (1968).

64. Santos (1940).

65. Cf. Almeida, op. cit. e Santos, op. cit.

66. A coroa real original foi fabricada no Brasil para D. João VI, por Inácio Luís da Costa, na oficina do ourives António Gomes da Silva, em 1817 , com $2,5 \mathrm{~kg}$ de ouro nativo e prata, $30,4 \mathrm{~cm}$ de altura e $38,5 \mathrm{~cm}$ de diâmetro. Atualmente pertence ao acervo do Palácio Nacional da Ajuda, localizado em Lisboa (Portugal).

67. Varnhagen (1857, p. 1169). A grafia original foi mantida.

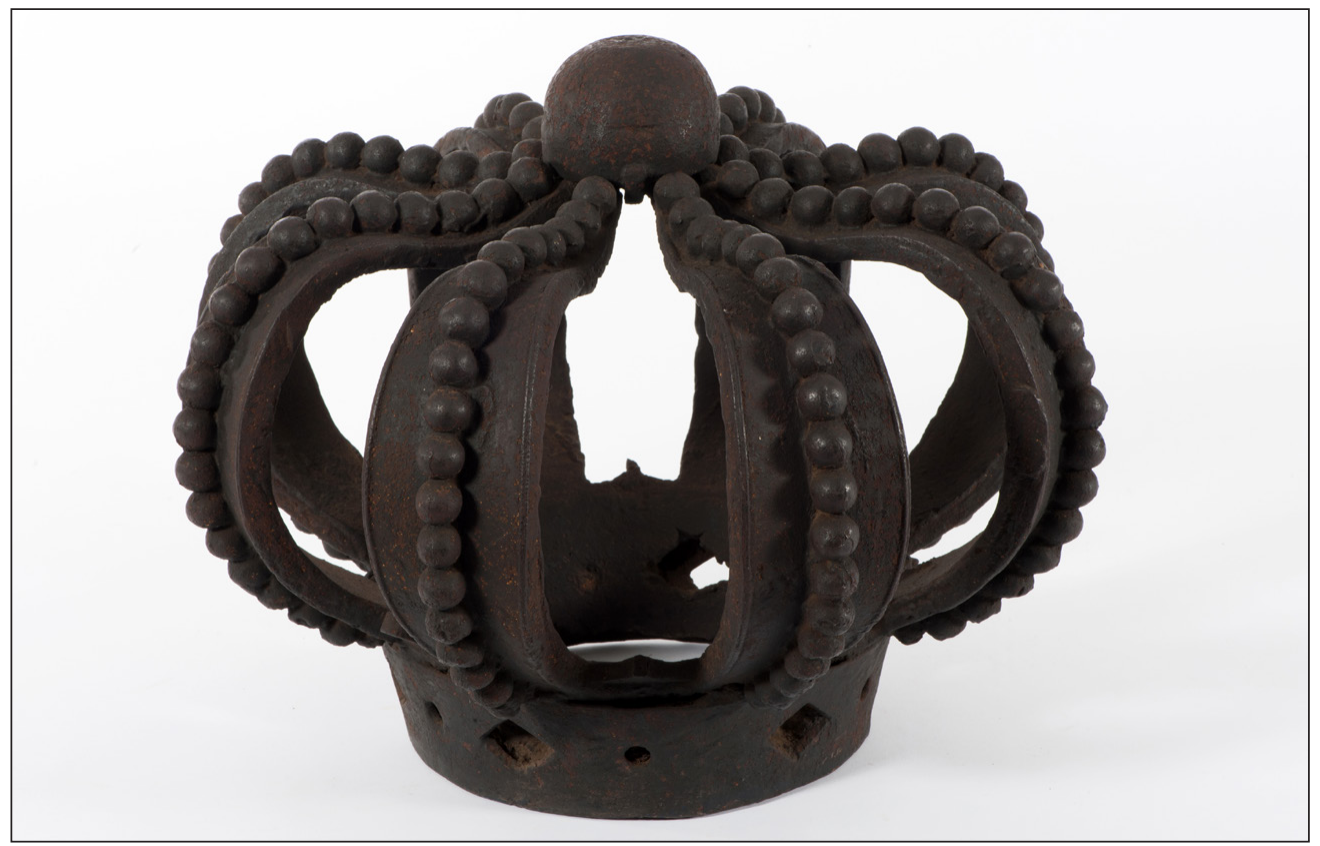

Figura 9 - Coroa de ferro fundido à semelhança da coroa imperial, de $34 \mathrm{~cm}$ de altura e $45 \mathrm{~cm}$ de diâmetro. Atribuída à Real Fábrica São João do Ipanema, 1815-21. 66 Fonte: Acervo do Museu Paulista (USP), São Paulo.

Embora a ficha catalográfica do Museu Histórico Nacional mencione que o casal real visitou a Fábrica em 1846 e, então, D. Teresa Cristina foi presenteada com o colar de ferro feito com o primeiro ferro de lpanema, não foram identificados registros desse momento. E a qual "primeiro ferro de lpanema" a ficha faz menção? Varnhagen menciona três cruzes de ferro feitas com o primeiro ferro de Ipanema em 1818, mas e em 1846? A ficha refere-se ao primeiro ferro de lpanema na confecção de uma joia de ferro? Ou ao primeiro ferro obtido a partir de uma nova tecnologia de extração ou beneficiamento?

E no dia de Todos os Santos, $1^{\circ}$ de novembro de 1818, o ferro fundido n'um dos fornos altos, corria liquido e candente pelos regos e ia coalhar-se nas fôrmas de três enormes cruzes, que ainda hoje se conservam inauguradas nas immediações. Varnhagen commoveu-se de júbilo, sem the passar pela mente a idéa do triunfo; e a todos os empregados, que todos estavam presentes, tratou de occultar as duas lagrimas que de alegria dos olhos the brotaram, dando-thes ordens para que passassem juntos á capela a render graças ao Altíssimo pela nova glória quo havia outorgado ao reinado do Sr. D. João. - A maior das mencionadas três cruzes, de mil e tantas libras de pezo, foi conduzida em procissão, e collocada no alto do visinho morro, em memória deste feliz successo tão glorioso para o seu inventor, como interessante para o Brazil, por attestar a origem de uma nova indústria. ${ }^{67}$ 
As dúvidas sobre a origem e a biografia do colar se mantêm, mesmo após menção de Francisco Varnhagen a objetos finos confeccionados em Ipanema, inclusive segundo modelos e tipos de Berlim, mas sem fazer referência ao colar:

\begin{abstract}
Deixou Varnhagen o estabelecimento com um credito em favor deste de quatorze mil cruzados de metal fornecido ao governo, e com uns sessenta mil cruzados era artigos armazenados. Além de munições de guerra e instrumentos aratorios e pregaria, etc., - se haviam executado obras delicadíssimas de ferro coado, e entre outras mencionaremos caixas de rape com o retrado d'elrei, castiçaes, quadros com os bustos de Schiller, de Göthe, e até um pequeno baixo-relevo da conhecida cêa de Da Vinci, tudo tão primorosamente feito, de um negro enfurnado tão igual, como os mais delicados artefactos de ferro que a Prússia fornece ao commercio. Destes artefactos nenhum infelizmente possuímos; mas ha muitas casas em Sorocaba, em S. Paulo e até no Rio onde ainda se conservam, e sentimos que nenhum exista no museo nacional; juntamente com coroa real de ferro, que ahi se mostra, tendo sido enviada por Varnhagen a elrei; e da qual a recepção e destino the foram anunciados por aviso do ministro Thomaz Antonío de 13 de novembro de 1820, e 11 de Janeiro de 1821.68
\end{abstract}

A primeira hipótese, ao início deste trabalho, se delineou a partir da legenda do colar de ferro em exposição e da ficha catalográfica do Museu Histórico Nacional (vide descrição no início do texto). A presença de especialistas prussianos no manejo do ferro em Ipanema, com o possível conhecimento da produção de joias de ferro, fortaleceu a proposição. Inferi, então, que o colar de ferro, creditado à lpanema, poderia ser um objeto-marco de discurso do processo civilizatório em meados do século XIX. Uma peça conforme o gosto do mundo civilizado, que determinaria valores, padrões, modos e modas que o representassem e o divulgassem. Poderia ser um objeto-marco por ter sido fabricado em São Paulo, no Brasil, nação então distante da capacidade produtiva e tecnológica europeia. Viria a ser símbolo do conhecimento europeu deslocado para motivar, moldar e aproximar o Brasil do progresso. Seria representante das iniciativas de atualização e adoção de tecnologia de metais estrangeira pelo Brasil imperial, dentro da iniciativa de Estado, que buscou adequar a jovem nação ao mundo moderno e às suas demandas materiais e imateriais. $\bigcirc$ colar de lpanema teria sido um presente para a Imperatriz, uma peça feminina, configurado segundo ditames da moda europeia e acompanhado da atmosfera de patriotismo, uma analogia à campanha prussiana de 1813-1815.

A ausência de indícios que comprovassem a hipótese primeira direcionou a busca para as coleções estrangeiras, guardiãs de peças semelhantes, e à trajetória do ferro de Berlim. Em mãos foi possível analisar 99 peças, em vitrines 14 peças, em catálogos e livros 128 peças, via internet (em acesso ao Leiloeiro 1 stDibs) vinte peças, e a museus 196 peças. Nesse levantamento e avaliação, constatei que peças foram 
69. Segundo Dawes e Davidov (op. cit.), os moldes das joias de ferro foram feitos em cera, que imprimiam suas formas em fina areia. O negativo da forma marcado, a areia era pulverizada de talco e preenchida com ferro fundido (mistura de ferro com $4 \%$ de carbono). A peça em ferro fundido passava a ter dimensões $1,4 \%$ menor que o molde.

70. Cabochão: lapidação convexa e arredondada, sem facetas.
Figura $10-O$ com- $^{-}$ ponente repetidor $B$ do colar do acervo do Museu Histórico $\mathrm{Na}$ cional (Ref. 13223) aparece como elemento repetidor do colar da Figura 11 e o componente C - em formato de palma como parte no colar da Figura 12. Fonte: Acervo do Museu Histórico Nacional. montadas a partir de partes de outras peças. É lógico! A fundição em areia, a partir de um molde, ${ }^{69}$ dá margem à multiplicação de partes, as quais podem ser montadas tantas vezes quantas a combinação entre elas permitir. Os exemplares, pelo princípio do processo de fabricação, pelo custo e pela oferta, deveriam ser numerosos - também inicialmente pela campanha, pois para receber joias de ouro o Estado prussiano não poderia arcar com o ônus de produzir peças caras para a troca. A produção das joias de ferro deveria ter custo mínimo, mas valor simbólico máximo.

Após as campanhas napoleônicas, os modelos circularam como objetos de moda, portanto a procura por esses artigos teve motivação e cenários outros que não os patrióticos. Joias que estiveram no gosto da boa sociedade atenderam ao decoro e às dinâmicas sociais, tiveram um passado que as associou a valores positivos e fabricantes que eram reconhecidos como especialistas, sendo premiados em espaços de legitimação de seu valor.

Ao longo do estudo de 457 itens, ficou claro que as peças têm partes de outras peças (Figuras 10, 11 e 12). As composições ora são semelhantes, ora iguais, ora híbridas, ora distintas. Dessa amostra, aspectos distintos foram apenas observados em parte das joias de ferro dos acervos do Österreichisches Museum für angewandte Kunst (Museu Austríaco de Artes Aplicadas), em Viena, e do Nordiska Museet (Museu Nórdico), em Estocolmo. Modelos feitos a partir de fios de ferro são distintos dos feitios prussianos, o que nos sugere o conhecimento e a competência no trabalho com esse metal. No museu vienense há também similares aos modelos prussianos, que receberam pequenos cabochões ${ }^{70}$ redondos de turquesa em centros de botões, brincos e broches.

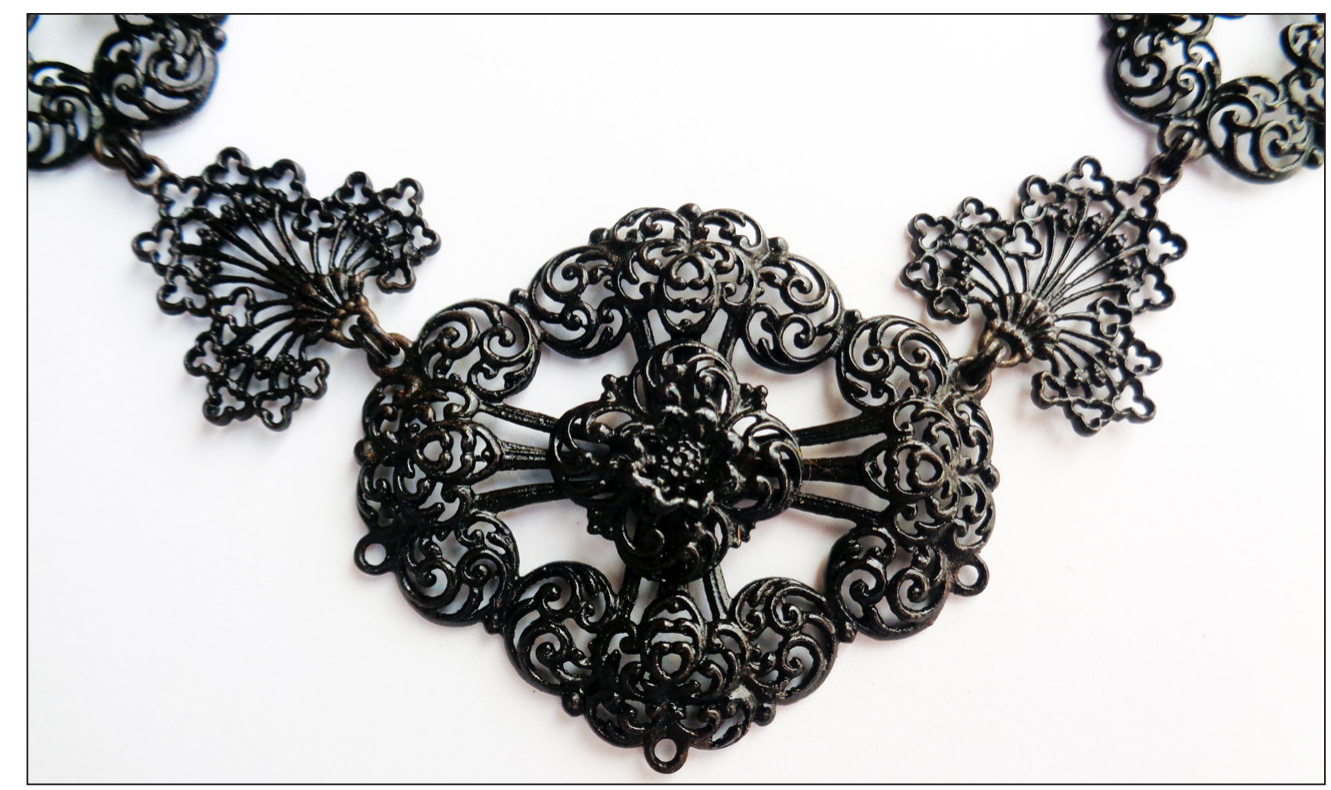




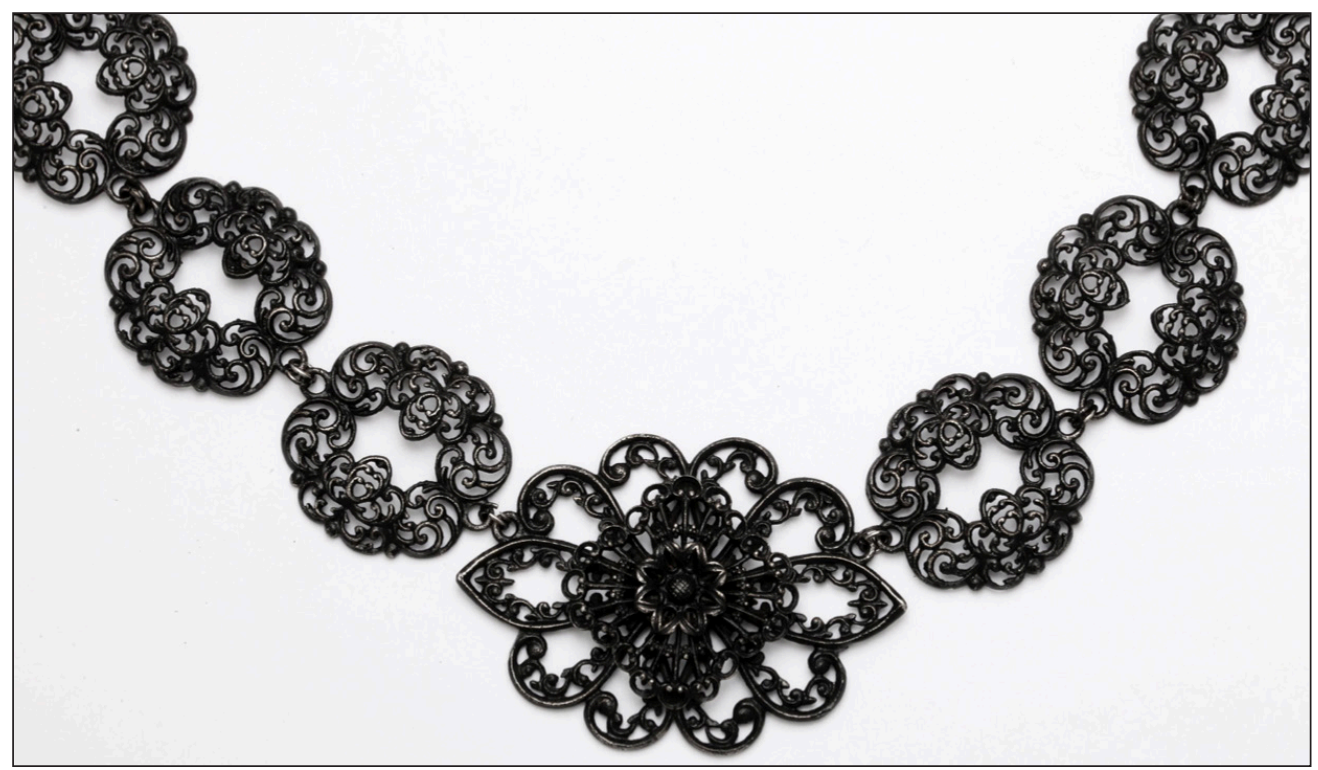

Figura 11 - Colar de ferro à venda no site 1stDibs (Ref. LU321038592). O colar é formado por peça central maior e a repetição de peças iguais ao componente B do colar do Museu Histórico Nacional (Ref. 13223). Fonte: 1 stDibs ([20-]).

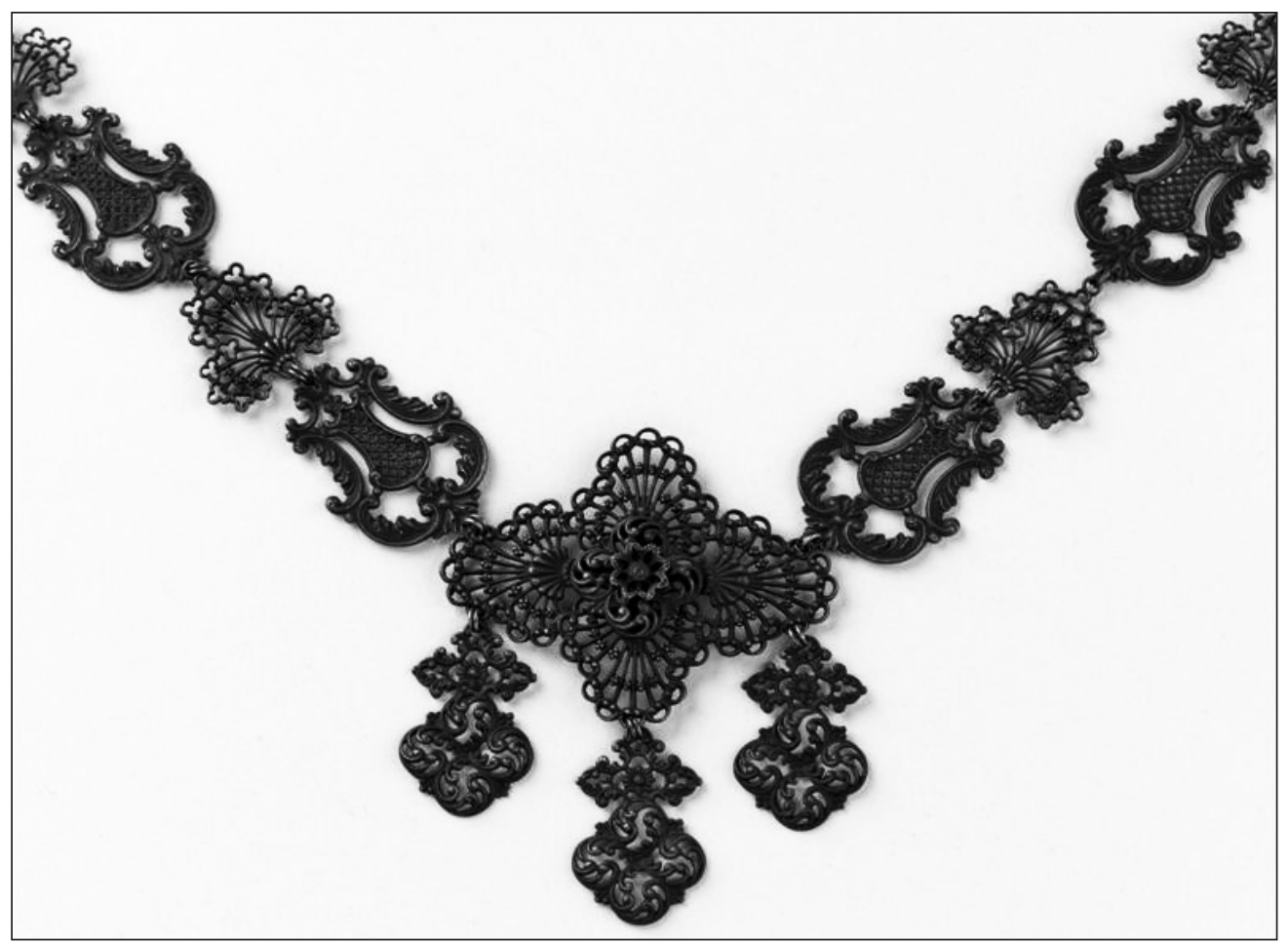

Figura 12 - Colar de ferro do acervo do Musée Le Secq des Tournelles (Ref. LS2003_1_418). O colar é formado por peça central com pingentes e o permeio entre elemento repetidor em forma de lira e de peças iguais ao componente $C$ do colar do Museu Histórico Nacional. Fonte: Acervo do Musée Le Seca des Tournelles. 
A avaliação desses acervos orientou a última hipótese sobre o colar de ferro do Museu Histórico Nacional. O colar não é único, não foi criado e confeccionado em São Paulo, na Real Fábrica de Ferro São João do Ipanema, com o primeiro ferro fundido em suas instalações. $\bigcirc$ delicado objeto foi montado a partir de 4 componentes - as peças A, B, C e o fecho (vide descrições em notas das Figuras 1, 2 e 3) -, moldados em matrizes europeias. Pela documentação consultada, tampouco foi presenteado pela empresa à Dona Teresa Cristina.

O colar está em ótimo estado de conservação e oferece outro indício curioso: três pequenas argolas equidistantes, fixadas no verso inferior do elemento central $A$, que indicam que três pingentes faltam à peça. Não sabemos se a ausência desses elementos é intencional ou se ocorreu alguma modificação na peça. Como são aparentes, é pouco provável que um colar incompleto tenha sido dado à Imperatriz. Para elucidar parte das dúvidas e organizar a biografia desse colar, referências sobre o doador são importantes. Até o presente este é o elo perdido de nosso estudo. Como o Sr. R. de Freitas Lima obteve o colar, caso este tenha sido da Imperatriz?

A peça, doada em 1927 para o então recém fundado Museu Histórico Nacional (1922), vem acompanhada de argumento legitimador para estar em um museu histórico nacional: ter pertencido à Imperatriz do Brasil. A história que lhe foi atribuída aumenta o seu valor perante os olhos da instituição e de quem o vê. Uma joia em consonância com a moda europeia, vinculada a discurso patriótico, civilizatório e ao progresso tecnológico, foi e é adequada ao espaço de exibição que the foi delegado. Não bastaria que o colar fosse de ferro à moda europeia oitocentista para ser doado e se tornar peça de museu. Mas, ter sido feito com o primeiro ferro extraído da Real Fábrica de Ferro São João do Ipanema, dado e pertencido à Imperatriz the deu e dá distinção perante as demais peças. $O$ vínculo com a casa real o tornaria testemunho da história nacional, um emblema da iniciativa e de um projeto de desenvolvimento; além de agente que divulgou modelos e valores civilizados e aproximou iguais. Se desapegado dessas qualidades, o objeto é apenas um belo colar de ferro, tipo raro nas modestas coleções de joalheria nacionais.

O conhecimento, reconhecimento e uso dos objetos da moda estiveram fortemente vinculados aos padrões de distinção das sociedades oitocentistas. A utilização do ferro - material bruto, rígido e resistente das armas, das ferramentas agrícolas e das máquinas - em artefatos refinados, com curvas e composições singelas, acabamento acurado que vincula seus usuários aos pares europeus, expressou o entusiasmo por um futuro de progresso, pela qualidade na produção, de conhecimento e domínio de técnicas e tecnologias modernas, mas também dos ideais patriotas e ações altruístas. E, mais uma vez, reitero que os objetos são 
resultantes de valores e intenções sociais, portanto coletivos, configurados pela experiência humana ao longo do tempo.

Organizar biografias sociais dos objetos ${ }^{71}$ é rica possibilidade de identificar e compreender as dinâmicas, relações e práticas sociais que os construíram e lhes deram agência. Artefatos, como o colar de ferro do Museu Histórico Nacional, são documentos históricos, que nos conduzem a pensar e rastrear trajetos, modos, técnicas e tecnologias que tornaram uma ideia e um material em um corpo. E, quando circulam, suas formas, dimensões, proporções, composições, ornamentos, aparência, componentes e mecanismos são conhecidos, desempenham mediações e desencadeiam efeitos em sociedade. A permanência, a ressignificação, o deslocamento, o desmonte, a reconfiguração ou a morte dos objetos nos conduzem às ações e transformações em sociedade; nos oferecem inúmeras possibilidades de estudos históricos e historiográficos, reflexões e debates. Neste exercício, "duvido que qualquer um de nós chegue às respostas definitivas. As perguntas mudam incessantemente e a história nunca pára", 72 pois, enquanto houver questões, conjecturas e enigmas, haverá história. 


\section{REFERÊNCIAS}

FONTES IMPRESSAS

Arquivo de São Paulo

Documentos 1.4.192.2 - Livro de registro de contratos de prestação de serviços. Grupo 5F10 - Agricultura, comércio e Obras Públicas, 1822-1896. 05 - Fábrica de São João de Ipanema (1822-1890): caixas C05213 [de 1811 a 1833] a C05217; Livros E0570, E0572, E0573, E04571, E04602, E04606.

Arquivo do Museu Imperial

I - AMI 4.2.890 - Com.c [Carta do Conde d'Algesur tratando da volta ao Brasil da dama da Imperatriz Viscondessa de Fonseca Costa e acusando o recebimento da mala da Imperatriz com tudo que tinha em seu quarto em Petrópolis].

Inventário das Joias - 1887 (Mordomia da Casa Imperial. Registros de Ofícios - XIX - 18861888, p. 84 e 88) apud Anuário do Museu Imperial, p. 259-265, 1943.

Santos, Francisco Marques. O leilão do Paço de S. Cristóvão. Anuário do Museu Imperial, v. 1, p. 151-210, 1940.

FONTES MANUSCRITAS

Arquivo do Museu Imperial

I - AMI 4.2.890 - Com.c [Carta do Conde d'Algesur tratando da volta ao Brasil da dama da Imperatriz Viscondessa de Fonseca Costa e acusando o recebimento da mala da Imperatriz com tudo que tinha em seu quarto em Petrópolis].

Trecho do Diário de D. Pedro II. Viagem a São Paulo - 18 a 31/06/1875 [sobre Fábrica de Ferro de São João de Ipanema]. 
LIVROS, ARTIGOS E TESES

ALMEIDA, Aluísio de. Memória história sobre Sorocaba (VIII). Revista de História, São Paulo, v. 37, n. 76, 1968, p. 355-356.

ARENHÖVEL, Willmuth; SCHREIBER, Christa; VORSTEHER, Dieter. Eisen statt Gold. Preußischer Eisenkunstguß aus dem Schloß Charlottenburg, dem Berlin Museum und anderen Sammlungen. Berlin: Siempelkamp, 1982.

BENNETT, David; MASCETTI, Daniela. Understanding jewellery. Suffolk: Antique Collectors' Club, 1999.

BOXER, Charles Ralph. A Idade do Ouro do Brasil: dores de crescimento de uma sociedade colonial. Tradução de Nair de Lacerda. Rio de Janeiro: Nova Fronteira, 2000.

BURY, Shirley. Jewellery gallery.: summary Catalogue. London: Victoria and Albert Museum, 1982.

CLIFFORD, Anne. Cut-steel and Berlin iron jewellery. Bath: Adams \& Dart, 1971.

CURL, James Stevens. Funerals, ephemera, and mourning. In: CURL, James Stevens. The Victorian Celebration of Death. Stroud: Sutton, 2001. p. 194-221.

DARNTON, Robert. O grande massacre dos gatos: e outros episódios da história cultural francesa. Tradução de Sonia Coutinho. Rio de Janeiro: Graal, 1986.

DAWES, Ginny Redington; DAVIDOV, Corinne. Victorian jewelry: unexplored treasures. New York: Abbeville, 1991.

DEAN, Warren. Ouro e diamantes, formigas e gado. In: DEAN, Warren. A ferro e fogo: a história e a devastação da Mata Atlântica brasileira. Tradução de Cid Knipel Moreira. São Paulo: Companhia das Letras, 1996. p. 108-133.

EVANS, Joan. A bistory of jewellery: 1110-1870. New York: Dover, 1989.

FIGUEIREDO, Lucas. Boa ventura! A corrida do ouro no Brasil (1697-1810). Rio de Janeiro: Record, 2011. 
FRANCO, Afonso Arinos de Melo. Desenvolvimento da civilização material no Brasil. Rio de Janeiro: Topbooks, 2005.

GERE, Charlotte; RUDOE, Judy. Jewellery in the age of Queen Victoria: a mirror to the world. London: British Museum Press, 2010.

INSTITUTO BRASILEIRO DE GEMAS E METAIS PRECIOSOS. Manual Técnico de Gemas. 3. ed. Brasília,DF: IBGM, 2005.

KLIAUGA, Andréa Madeira; FERRANTE, Maurizio. Metalurgia básica para ourives e designers: do metal à joia. São Paulo: Blucher, 2009.

KOPYTOFF, Igor. A biografia cultural das coisas: a mercantilização como processo. In: APPADURAI, Arjun (org.). A vida social das coisas: as mercadorias sob uma perspectiva cultural. Tradução de Agatha Bacelar. Niterói: Editora da Universidade Federal Fluminense, 2008. p. 89-121.

LANDGRAF, Fernando. Sobrou "Fer de Berlin" made in Brazil? São Paulo: [S. n.], 2018.

LANDGRAF, Fernando; ARAÚJO, Paulo Eduardo Martins. A arquitetura do alto-forno e a biblioteca perdida de Ipanema: técnica e conhecimento no Brasil Joanino. In: SEMINÁRIO NACIONAL DE HISTÓRIA DA CIÊNCIA E TECNOLOGIA, 14., 2014. Anais [...]. Belo Horizonte: UFMG, 2014.

LANDGRAF, Fernando; TSHIPTSCHIN, André ; GOLDSTEIN, Hélio. Notas sobre a História da Metalurgia no Brasil (1500-1850). In: VARGAS, Milton (org.). História da técnica e da tecnologia no Brasil. São Paulo: Editora Unesp, 1994. p. 107-129.

LIMA, Marco Antonio Magalhães. Introdução aos materiais e processos para designers. Rio de Janeiro: Ciência Moderna, 2006.

LOBO, Rodrigo. Fábrica de Ferro de São João do Ipanema. MAPA - Memória da Administração Pública Brasileira, Brasília (DF), 10 nov. 2016. Disponível em: https://bit.ly/3adKWdE. Acesso em: 11 fev. 2021.

MONTEIRO, Bertholdo de Castro. Pedras brasileiras. Rio de Janeiro: Reler, 2004.

MORLEY, John. Death, heaven and the victorians. London: Studio Vista, 1971. 
MÜLLER, Elisa; OLIVEIRA, Geraldo de Beauclair Mendes. Reflexões sobre a história da fábrica de ferro São João do Ypanema. In: ENCONTRO NACIONAL DE ECONOMIA, 18., 1990, Brasília. Anais [...]. Brasília, DF: ANPEC, 1990. p. 1247-1262.

PHILLIPS, Clare. Jewels and jewellery. London: Victoria and Albert Publications, 2000.

PHILLIPS, Clare. Jewels from antiquity to the present. London: Thames \& Hudson, 2006.

PRADO JÚNIOR, Caio. Formação do Brasil contemporâneo: colônia. São Paulo: Companhia das Letras, 2011.

SANTINI, Valesca Henzel; BARBURY, Heloisa. Fontes para o estudo da joalheria do século XIX: as exposições universais. Ensinarmode, Florianópolis, v. 3, n. 3, p. 54-67, 2020.

SANTOS, Irina Aragão. Celtas e romanos: interações culturais através dos adornos pessoais. 2006. Monografia (Graduação em História) - Instituto de Filosofia e Ciências Sociais, Universidade Federal do Rio de Janeiro, Rio de Janeiro, 2006.

SANTOS, Irina Aragão. Joias de afeto: um catálogo de referências. 2009. Dissertação (Mestrado em História Comparada) - Instituto de Filosofia e Ciências Sociais, Universidade Federal do Rio de Janeiro, Rio de Janeiro, 2009.

SANTOS, Irina Aragão. Tramas de afeto e saudade: em busca de uma biografia dos objetos e práticas vitorianos no Brasil oitocentista. 2014. Tese (Doutorado em História Comparada) Instituto de História, Universidade Federal do Rio de Janeiro, Rio de Janeiro, 2014.

SANTOS, Nilton Pereira. A fábrica de ferro São João de Ipanema: economia e política nas últimas décadas do Segundo Reinado (1860-1889). 2009. Dissertação (Mestrado em História) - Faculdade de Filosofia, Letras e Ciências Humanas, Universidade de São Paulo, São Paulo, 2009.

SCHMITT, Juliana. Mortes vitorianas: corpos, luto e vestuário. São Paulo: Alameda, 2010.

SCHUMANN, Walter. Gemas do mundo. Tradução de Rui Ribeiro de Franco e Mario Del Rey. Rio de Janeiro: Ao Livro Técnico, 1990.

SCHWARCZ, Lilia Moritz. As barbas do imperador: D. Pedro II, um monarca dos trópicos. São Paulo: Companhia das Letras, 1999. 
TAYLOR, Lou. Mourning dress: a costume and social history. London: George Allen \& Unwin, 1983.

UNTRACHT, Oppi. Jewelry concepts and technology. New York: Doubleday, 1985.

VAINFAS, Ronaldo. Dicionário do Brasil imperial. Rio de Janeiro: Objetiva, 2002.

VARNHAGEN, Francisco Adolfo. História geral do Brasil: antes da sua separação e independência de Portugal. Rio de Janeiro: E. \& H. Laemmert, 1857. t. 2.

VERNE, Júlio. Da Terra à Lua: viagem em 97 horas e 20 minutos. Tradução de Gustavo de Azambuja Feix. Porto Alegre: L\&PM, 2018.

SITES

1STDIBS. Jewelry \& Watches. New York, [20-]. Disponível em: <https://bit.ly/2OsHymt>. Acesso em: 19 fev. 2019.

INSTITUTO CHICO MENDES DE CONSERVAÇÃO DA BIODIVERSIDADE. Floresta Nacional de Ipanema. Brasília, 17 out. 2012. Disponível em: <https://bit.ly/2OBogf3>. Acesso em: 6 dez. 2018.

ART OF MOURNING. Textiles Tuesday: 19th century, part 2. Brighton, [20-]. Disponível em: $<$ https://bit.ly/3d6sTYq>. Acesso em: 3 nov. 2013.

VICTORIA AND ALBERT MUSEUM. Bracelet: Geiss, Johann Conrad. London, 15 jun. 2012. Disponível em: <https://bit.ly/3pfG4ZE>. Acesso em: 17 fev. 2019.

VICTORIA AND ALBERT MUSEUM. Fan: Schott, Edward. London, 10 ago. 2005. Disponível em: <https://bit.ly/3aWFj2E >. Acesso em: 17 fev. 2019.

VICTORIA AND ALBERT MUSEUM. From the collections. London, 3 jun. 2010. Disponível em: <https://bit.ly/3b4af0Z>. Acesso em: 21 fev. 2019.

Artigo apresentado em: 25/7/2020. Aprovado em 22/12/2020.

(cc) BY

All the contents of this journal, except where otherwise noted, is licensed under a Creative Commons Attribution Licens 